Article

\title{
Postmortem Documentation of SARS-CoV-2 in Utero and Postpartum Transmission, through Amniotic Fluid, Placental, and Pulmonary Tissue RT-PCR
}

\author{
Alexandra Enache ${ }^{1,2}$, Veronica Ciocan $1,2,+$, Camelia Oana Muresan $1,2,+$, Talida Georgiana Cut 2,3,4,*D, \\ Dorin Novacescu $^{4, *}$, Corina Paul ${ }^{5,+} \mathbb{D}$, Nicoleta Andreescu ${ }^{6} \mathbb{D}$, Alexandra Mihailescu ${ }^{6}$, Marius Raica ${ }^{7,8,+}$ \\ and Raluca Dumache ${ }^{1,2}$
}

Citation: Enache, A.; Ciocan, V.; Muresan, C.O.; Cut, T.G.; Novacescu, D.; Paul, C.; Andreescu, N.; Mihailescu, A.; Raica, M.; Dumache, R. Postmortem Documentation of SARS-CoV-2 in Utero and Postpartum Transmission, through Amniotic Fluid, Placental, and Pulmonary Tissue RT-PCR. Appl. Sci. 2021, 11, 9505. https://doi.org/ 10.3390/app11209505

Academic Editor: Caroline Wilkinson

Received: 21 September 2021

Accepted: 11 October 2021

Published: 13 October 2021

Publisher's Note: MDPI stays neutral with regard to jurisdictional claims in published maps and institutional affiliations.

Copyright: (c) 2021 by the authors. Licensee MDPI, Basel, Switzerland. This article is an open access article distributed under the terms and conditions of the Creative Commons Attribution (CC BY) license (https:/ / creativecommons.org/licenses/by/ $4.0 /)$.
1 Department VIII, Discipline of Forensic Medicine, Bioethics, Deontology and Medical Law, Victor Babes University of Medicine and Pharmacy Timisoara, E. Murgu Square, Nr. 2, 300041 Timisoara, Romania; enache.alexandra@umft.ro (A.E.); veronica.luta@umft.ro (V.C.); dr_muresan_camelia@yahoo.com (C.O.M.); raluca.dumache@umft.ro (R.D.)

2 Center for Ethics in Human Genetic Identifications, Victor Babes University of Medicine and Pharmacy Timisoara, E. Murgu Square, Nr. 2, 300041 Timisoara, Romania

3 Department XIII, Discipline of Infectious Diseases, Victor Babes University of Medicine and Pharmacy Timisoara, E. Murgu Square, Nr. 2, 300041 Timisoara, Romania

4 Doctoral School, Victor Babes University of Medicine and Pharmacy Timisoara, E. Murgu Square, Nr. 2, 300041 Timisoara, Romania

5 Department XI, Discipline of Pediatrics, Victor Babes University of Medicine and Pharmacy Timisoara, E. Murgu Square, Nr. 2, 300041 Timisoara, Romania; paul.corina@umft.ro

6 Department II, Discipline of Genetics, Victor Babes University of Medicine and Pharmacy Timisoara, E. Murgu Square, Nr. 2, 300041 Timisoara, Romania; andreescu.nicoleta@umft.ro (N.A.); mihailescu.alexandra@umft.ro (A.M.)

7 Department II, Discipline of Histology, Victor Babes University of Medicine and Pharmacy Timisoara, E. Murgu Square, Nr. 2, 300041 Timisoara, Romania; marius.raica@umft.ro

8 Angiogenesis Research Center, Victor Babes University of Medicine and Pharmacy Timisoara, E. Murgu Square, Nr. 2, 300041 Timisoara, Romania

* Correspondence: talida.cut@umft.ro (T.G.C.); dorin.novacescu@yahoo.com (D.N.); Tel.: +40-755-690-250 (T.G.C.); +40-751-215-549 (D.N.)

+ The authors have equal contribution.

Abstract: The physiopathology of SARS-CoV-2 infection, during pregnancy and in early childhood, is poorly understood. Unfavorable maternal outcomes, the risk of vertical/postpartum transmission, and severe, multisystem involvement in infants and children highlight the importance of developing a cohesive treatment and nuanced prophylaxis strategy. In this study, we evaluate autopsy reports, pathological findings, and SARS-CoV-2 genome expression in three distinct clinical scenarios: maternal death due to severe COVID-19 with in utero fetal demise (27 weeks); mother with moderate COVID-19 and in utero fetal demise (29 weeks); and 2-month-old infant death with confirmed COVID-19 caregivers. We report the presence of the SARS-CoV-2 genome in amniotic fluid and placental tissue in the context of in utero transmission of SARS-CoV-2, but also in postmortem infant pulmonary tissue samples in a case of late postpartum SARS-CoV-2 transmission with asymptomatic, rapidly progressive disease, resulting in infant death. Key pathological findings offer a descriptive portrayal of maternal, in utero, and infantile COVID-19 pathogenesis. Further investigations are necessary to fully comprehend the clinical implications of SARS-CoV-2 infection during pregnancy, a prerequisite for adequate therapeutic management and harm reduction.

Keywords: SARS-CoV-2; pregnancy; vertical transmission; postpartum transmission; autopsy; fetal demise; amniotic fluid RT-PCR; placenta RT-PCR; pulmonary tissue RT-PCR; multisystem inflammatory syndrome in children (MIS-C) 


\section{Introduction}

Since being firstly documented at the end of 2019, in Wuhan (China), the corona-virus disease 2019 (COVID-19), a zoonotic infection caused by severe acute respiratory syndrome coronavirus 2 (SARS-CoV-2), has spread rampantly, raising major public health concerns and applying continuous strain on the global medical infrastructure. With roughly 212 million confirmed cases worldwide and a current mortality rate of just over 2\% [1], COVID-19 was officially declared a pandemic by the World Health Organization (WHO) on 11 March 2020 [2]. Due to the wide variability in incubation periods (usually 1-14 days, with some reports of $>24$ days [3]) and the extreme polymorphism of clinical presentations, ranging from asymptomatic to acute respiratory distress syndrome (ARDS), the containment of transmission and therapeutic management of COVID-19 has proved to be quite challenging for clinicians, especially in the case of high-risk patients.

Beyond the well-documented comorbidities involved in disease severity (i.e., cardiovascular diseases, diabetes mellitus, and other pre-existing respiratory afflictions), emerging data on SARS-CoV-2 infection during pregnancy, both regarding maternal outcomes and the risk of vertical/neonatal transmission, highlight the importance of developing a cohesive treatment and nuanced prophylaxis strategy.

The enveloped, positive-sense RNA single-stranded SARS-CoV-2, a novel member of the $\beta$-coronavirus genus [4], represents the third highly pathogenic coronavirus since the early 2000s, after severe acute respiratory syndrome coronavirus (SARS-CoV) and Middle East respiratory syndrome coronavirus (MERS-CoV), to infect humans and cause a large-scale outbreak [5]. Although mortality rates are lower for SARS-CoV-2 than for previous outbreaks ( $>10 \%$ for SARS-CoV and $>35 \%$ for MERS-CoV [6]), contagiousness is much higher, as transmission occurs primarily through respiratory droplets, with multiple alternative mechanisms being reported (aerosols, direct contact with contaminated surfaces, and fecal-oral transmission [5]). With 10,000 cumulative cases between them, SARS$\mathrm{CoV}$ and MERS-CoV have never been documented to manifest vertical transmission [7]. However, the extremely low number of infected pregnant women reported (12 for SARS$\mathrm{CoV}$ and 11 for MERS-CoV) is insufficient to formulate a definitive conclusion, yet we must note that an overwhelming majority of these cases presented a variety of complications and adverse clinical outcomes (maternal death, miscarriage, premature delivery, intensive care admission for newborns, and perinatal death) [8]. Moreover, other emerging viral infections (Zika, Ebola, Marburg, and Influenza H1N1) have been known to manifest a wide range of threats to maternal and fetal outcomes [9-13], thus the possibility/implications of SARS-CoV-2 vertical and postpartum transmission mandate thorough investigation.

Pregnancy, due to the physiological maternal adaptations it entails, i.e., cardiovascular (cardiac strain, endothelial dysfunction, and hypercoagulability $[14,15])$, respiratory (estrogen/progesterone-induced edema of the upper respiratory tract and anatomical modifications resulting in restricted lung expansion and the inability to clear bronchial secretions [16-18]), and immunologic (alterations in inflammatory activity and cell-/antibodymediated immune response depending on gestational age [14,16-18]), is known to increase the risk of severe clinical manifestations in response to viral infections, and this paradigm seemingly holds true for SARS-CoV-2 as well [19].

Although early systematic reviews regarding maternal outcomes in COVID-19 during pregnancy reported no clinical differences between COVID-19 in pregnant and nonpregnant patients [20], and even that pregnant patients were less likely to manifest COVID19 symptoms, in the case of infection, than non-pregnant patients with COVID-19 [21], these reviews were seemingly biased by low-quality data (case reports and case series) and erroneous control groups (non-pregnant patients or none whatsoever). A recent meta-analysis, however, shows that COVID-19 in pregnancy increases the prevalence of pre-eclampsia [22], stillbirth, and preterm birth compared to non-COVID-19 pregnancies, and that symptomatic COVID-19 increased the risk of cesarean delivery and preterm birth compared to asymptomatic COVID-19, while also indicating a stronger association of 
pre-eclampsia, gestational diabetes, preterm birth, and low birth weight, with an increasing severity of COVID-19 during pregnancy [23].

The SARS-CoV-2 lifecycle is highly dependent on one of its four structural proteins: the envelope spike protein, which mediates viral genome entry into host cells [24], via direct contact between the spike receptor-binding domain and the innate cellular receptor angiotensin-converting enzyme 2 (ACE2) [25]. After initial binding, efficient host cell entry is dependent upon adequate cleavage of the viral spike S1/S2 polybasic cleavage site by two host cell proteolytic enzymes: transmembrane protease serine 2 (TMPRSS2), allowing surface-cell membrane entry, and endolysosomal cathepsin L, responsible for spike activation in endosomes and virus-cell membrane fusion at the level of the cell surface and endosomal compartments, allowing entry into TMPRSS2-deficent cells [26-28]. Once the viral RNA genome is released into the host cell cytosol, viral replication ensues, hijacking the host cell translational and transcriptional apparatuses and driving new virion formation, with subsequent expulsion into the intercellular space.

The main tissue tropism of SARS-CoV-2 is pulmonary, targeting high-ACE2-expression cells (airway/alveolar epithelial cells, vascular endothelial cells, and alveolar macrophages) [29-32]. Yet, extra-pulmonary tissues manifest higher levels of ACE2 mRNA expression [33]; therefore, additional, underappreciated, and cell-intrinsic factors must also be involved in host cell entry [25], seeing as nearly undetectable amounts of ACE2 still support viral host cell entry in the presence of TMPRSS2 [34]. Moreover, a subpopulation of human type II alveolar cells, with abundant ACE2 expression, and concomitant higher levels of mRNA, specific to certain cellular pro-viral genes (related to the endosomal transport system, which promotes SARS-CoV-2 cell entry), has been documented [35]. Additionally, ACE2 expression regulation must be considered, as, during viral infection, ACE2 gene expression in human airway epithelial cells is upregulated by type I and II interferons [32,36].

Nevertheless, an early increase in all the components of the renin-angiotensin -aldosterone system, including ACE2, represents one of the physiological hormonal alterations pregnancy entails, and may increase the risk of maternal SARS-CoV-2 infection $[37,38]$. Conversely, the expression of both ACE2 and TMPRSS2 has been documented in human fetal lung tissue, as well as other fetal tissues [39,40], and in placental cells [41], even though the extent of co-expression, and differential expression in accordance with gestational age, remain controversial [42,43]. ACE2 expression has been documented throughout the maternal-fetal interface (villous syncytiotrophoblast and cytotrophoblast, endothelium and vascular smooth muscle from both primary and secondary villi [44,45], decidual cells [39], and Hofbauer cells [46]) and the female reproductive tract (ovary, uterus, and vagina [47]).

Thus, hematogenous vertical transmission of SARS-CoV-2 is biologically plausible, seeing as SARS-CoV-2 viremia, although generally infrequent, appears to be more likely to occur in those with severe disease $[48,49]$. Furthermore, due to SARS-CoV-2-associated vascular damage and hypercoagulability in pregnant women, multiple reports have described common patterns of histopathological modifications in placental specimens (fetal and/or maternal vascular malperfusion [50], intramural fibrin deposition [51], and chronic villitis or intervillositis [45], even central and peripheral villous infarctions [52]). Therefore, in the context of ischemic placental injury, SARS-CoV-2 could obtain access to fetal circulation via placental barrier disruption, infecting the fetus without requiring placental cell infection [49].

Although SARS-CoV-2 RNA has rarely been detected on vaginal mucosa swab specimens of infected pregnant women [53,54], fecal shedding of the pathogen is wellestablished and frequent (43\%) [55]. In the case of vaginal birth, fecal contamination of the birth canal during labor/childbirth may potentially facilitate SARS-CoV-2 intrapartum transmission, via viral contamination of the neonatal oro/nasopharynx [56]. On the other hand, droplets/aerosols generated during active labor by the infected mother, as well as maternal fecal expulsion during vaginal birth, may determine SARS-CoV-2 contami- 
nation of the nearby environment, which, in turn, will facilitate infection of the neonate immediately after birth [57]. For this reason, making a definitive distinction between intrapartum (vertical) and immediate postpartum (horizontal) transmission of SARS-CoV-2 is quite difficult.

Even so, the majority of neonatal SARS-CoV-2 infections reported have seemingly occurred in the postpartum setting, most likely in the context of exposure to the infected mother, other caregivers, or contaminated objects/surfaces $[53,58]$. Breastfeeding represents another possible mechanism for postpartum SARS-CoV-2 transmission and, although various guidelines have endorsed the relative safety of breastfeeding while infected $[59,60]$, the topic is still highly controversial. To date, no replication-competent virus has been detected in breast milk, yet the presence of SARS-CoV-2 RNA has been documented through reverse transcription polymerase chain reaction (RT-PCR)-based assays [61]. Conversely, breast milk has been documented to contain SARS-CoV-2-specific IgG, IgM, and IgA [62,63], but the protective value of the antibodies in a breastfed infant is still unclear.

In light of recent and amounting clinical data supporting mother-to-child transmission of SARS-CoV-2, the WHO has released a guideline for adequate case definition and stratification of timing regarding this phenomenon, in an effort to standardize diagnosis in clinical practice and homogenize scientific reporting [49].

In this study, we report the presence of the SARS-CoV-2 genome in amniotic fluid and placental tissue samples in the context of in utero transmission of SARS-CoV-2 with fetal demise, but also in postmortem infant pulmonary tissue samples in a case of late postpartum transmission of SARS-CoV-2 with asymptomatic, rapidly progressive disease, resulting in infant death. Furthermore, key modifications encountered during autopsy and pathological tissue sample analysis offer a descriptive portrayal of maternal, in utero, and infantile COVID-19 pathogenesis, serving to further our understanding of the clinical implications of SARS-CoV-2 infection during pregnancy, a prerequisite for adequate therapeutic management.

\section{Materials and Methods}

Since the beginning of the pandemic, during daily forensic practice, we have evaluated 310 cases of suspected COVID-19-related deaths, which underwent mandatory autopsy under Romanian legislation [64] at the Institute of Legal Medicine in Timisoara, Romania, and we have identified 3 distinct cases useful in evaluating vertical transmission and maternal-fetal outcomes in COVID-19 pregnancies:

- $\quad$ Maternal death due to severe COVID-19 and in utero fetal demise (27 weeks).

- In utero fetal demise (29 weeks) with living confirmed COVID-19 mother.

- 2-month-old infant death with confirmed COVID-19 caregivers.

Autopsies and tissue/fluids manipulation were done with personnel using PPE, in accordance with the Romanian Health Ministry recommendations. Full-body autopsy (inspection of cranial, thoracic, and abdominal cavities) was performed in all cases. The autopsies were performed from 24 to $48 \mathrm{~h}$ following death. Photographs were taken.

Multiple tissue specimens (pulmonary, nervous, cardiac, renal, hepatic, and placental) were collected for each case, fixed in $10 \%$ buffered formalin for $48 \mathrm{~h}$ and embedded in paraffin. For microscopic pathological analysis, 5 - $\mu$ m-thick sections were obtained and stained with hematoxylin and eosin.

Fresh biological specimens were also collected, within each autopsy, and stored in RNAlater stabilization solution at $-20{ }^{\circ} \mathrm{C}$, as follows: for the first case, amniotic fluid, and placenta specimens; for the second case, placenta specimens; and for the third case, pulmonary tissue specimens. All of these specimens were then evaluated through RT-PCR for SARS-CoV-2 RNA following the subsequent steps:

\subsection{Manual Pre-Processing}

Using a $1.5 \mathrm{~mL}$ Eppendorf tube (Eppendorf, Hamburg, Germany), a lysis solution consisting of $200 \mu \mathrm{L}$ of lysis buffer, $20 \mu \mathrm{L}$ proteinase K solution, and $20 \mu \mathrm{L}$ of internal 
extraction control (IEC) was prepared (Primerdesign, Camberley, UK). In another $1.5 \mathrm{~mL}$ sterile cryotube, $100 \mu \mathrm{L}$ of blood sample was added to the lysis solution and the obtained solution was vortexed for $10 \mathrm{~s}$. The mixture solution was then incubated for $10 \mathrm{~min}$ at $56^{\circ} \mathrm{C}$ in an Eppendorf Thermo Mixer C (Eppendorf, Hamburg, Germany).

\subsection{Automated RNA Extraction}

The automated RNA extraction was performed using a Maxwell 48 RSC System (Promega, Madison, WI, USA) and a Maxwell RSC Viral Total Nucleic Acid Purification kit (Promega, Madison, WI, USA).

\subsection{Amplification of the Products}

After the viral RNA extraction, the master mix solution was prepared using the Coronavirus COVID-19 kit (Primerdesign, Camberley, UK). The reagents were $10 \mu \mathrm{L}$ of Oasig ${ }^{\mathrm{TM}}$ OneStep 2xRT qPCR Master Mix and $2 \mu \mathrm{L}$ of COVID-19 and IEC Primer/Probe. After the preparation, $12 \mu \mathrm{L}$ of the master mix solution was added to the PCR wells on a plate followed by $8 \mu \mathrm{L}$ of sample, positive control template (PCT) and negative extraction control (NEC). The PCR plate was sealed with a MicroAmp ${ }^{\mathrm{TM}}$ Optical Adhesive film (Thermo Fisher Scientific, Waltham, MA, USA) and gently centrifuged to the PCR plate using the Axygen Mini Plate Spinner Centrifuge (Corning, Corning, CA, USA) to collect the contents at the bottom of the plate (Table 1).

Table 1. Amplification steps following recommendations for genesig ${ }^{\circledR}$ Real-Time PCR Assay (Primerdesign, Camberley, UK).

\begin{tabular}{cccc}
\hline Steps & Time & Temperature & Cycles \\
\hline 1. Reverse transcription & $10 \mathrm{~min}$ & $55^{\circ} \mathrm{C}$ & 1 \\
2. Denaturation (Taq activation) & $2 \mathrm{~min}$ & $95^{\circ} \mathrm{C}$ & 1 \\
3. Denaturation & $10 \mathrm{~s}$ & $95^{\circ} \mathrm{C}$ & 45 \\
4. Annealing and extension & $60 \mathrm{~s}$ & $60^{\circ} \mathrm{C}$ & \\
\hline
\end{tabular}

\section{Results}

\subsection{Case One: Maternal Death due to Severe COVID-19 and In Utero Fetal Demise}

A 39-year-old Caucasian woman, 28-weeks pregnant, gesta 5 para 4, with a known history of insulin-dependent type II diabetes mellitus, obesity class I, and gestational hypertension, presented to the emergency department, complaining of fever, shortness of breath, and intense abdominal pain. Laboratory tests revealed an increased white blood cell count $\left(11,000 / \mathrm{mm}^{3}\right)$, normal kidney function, elevated hepatic enzymes (ALAT: $86 \mathrm{U} / \mathrm{L}$, ASAT: $75 \mathrm{U} / \mathrm{L})$, and increased C-reactive protein $(88.5 \mathrm{mg} / \mathrm{L})$. Bilateral interstitial pneumonia was found after conducting a chest X-ray. Nasopharyngeal swabs, obtained from the emergency department, tested positive for SARS-CoV-2 RNA amplification. Due to severe inspiratory dyspnea (oxygen saturation: $88 \%$ in room air), the patient was admitted to the intensive care unit (ICU) for further investigations and specialized treatment. Upon ICU admission, the patient was hemodynamically stable with an oxygen saturation of $95 \%$ on facial mask, heart rate of 90 beats/minute, and BP of 135/85 mmHg. On obstetrical exam: absent painful uterine contractions, rhythmic fetal heartbeat, active fetal movements present, normal uterine tonus, maintained cervix with intact membranes, and pelvic presentation. Following the Romanian healthcare guidelines for SARS-CoV-2 infection, intravenous treatment with dexamethasone sodium phosphate $8 \mathrm{mg}$, three times per day, empiric antibiotic therapy with third-generation cephalosporin (ceftriaxone), and subcutaneous low-molecular-weight heparin was initiated. Other drugs such as paracetamol, salbutamol, and vitamins were administered. Due to repeated oxygen desaturation episodes and the patient's low compliance in keeping the facial oxygen mask on, non-invasive ventilation was initiated. Within $48 \mathrm{~h}$ from admission, a rapid alteration of the patient's hemodynamic and biological parameters mandated a transfer towards a more specialized obstetrical COVID ICU department, with adequate management knowledge and equipment. Upon 
transfer admission, the patient presented with severe coma (Glasgow Coma Score 5) and cardiac arrest. Cardiopulmonary resuscitation maneuvers were initiated and emergency echographic evaluation of fetal viability was performed. Fetal demise was supported by a lack of active fetal movements and an absent fetal heartbeat. Maternal cardiopulmonary resuscitation failed after three attempts and the time of death was called. Due to the unknown exact cause of maternal-fetal demise, in accordance with Romanian legislation, a mandatory autopsy was performed.

\subsubsection{Relevant Autopsy Findings}

External examination of the body: height $168 \mathrm{~cm}$, abdominal obesity, purple-reddish lividities on the dorsal side of the body, on the anterior and superior thorax, in the imbibition phase, and sternal fracture due to CPR maneuvers.

Internal examination of the body: purple-reddish lungs with increased consistency, anthracotic pigmentation and multiple subpleural petechiae. Upon palpation, absent or reduced crepitations; on the section surfaces there is a low-volume leakage of liquid blood and yellow purulent mucus from intrapulmonary bronchi.

The uterus is flaccid, with a gray-purple serosa, and measures $26 \mathrm{~cm}$ longitudinally, $24 \mathrm{~cm}$ latero-laterally, with a thickness of $15 \mathrm{~cm}$, and, upon examination, a milky, yellowgrayish liquid and a female fetus are observed.

The 27-week fetus was analyzed: weight $1560 \mathrm{~g}$, height $39 \mathrm{~cm}$, and a cranial perimeter of $27 \mathrm{~cm}$; thoracic perimeter $25 \mathrm{~cm}$, and an abdominal perimeter of $24 \mathrm{~cm}$. The fetus presents epidermal desquamation on the distal lower limbs. The skin is reddish-purple, covered with vernix caseosa. The placenta is inserted on the left uterine wall and weighs $320 \mathrm{~g}$. The umbilical cord is $50 \mathrm{~cm}$ long, milky, and turgid.

On the right wall of the uterus, an ovoid, elastic tumor formation of $10 / 10 \mathrm{~cm}$ is observed, with intimate adherence to the uterine wall and intraparietal interest.

\subsubsection{Microscopic Findings}

Leptomeningeal vascular microthrombosis, cerebral edema, brainstem with mild vascular stasis, and edema in fetal brain tissue fragments (Figure 1). Unremarkable pulmonary, cardiac, and renal histology.

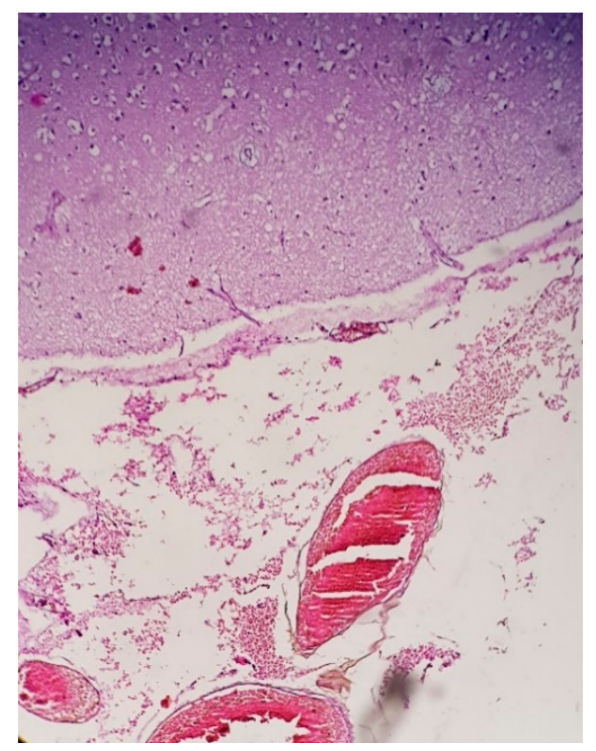

Figure 1. $100 \times$ hematoxylin-eosin (HE) stain of fetal brain tissue fragment demonstrating leptomeningeal vascular microthrombosis and red blood cell extravasation, meningeal edema, and nervous tissue without major modifications. 
Maternal myocardiosclerosis and cardiac lipomatosis, accompanied by interstitial pneumonia, with diffuse alveolar involvement characterized by squamous, serous, and sero-fibrinous alveolitis, production of hyaline membranes that begin to line the alveolar walls, pulmonary vascular thrombosis, and pleural vascular microthrombosis (Figure 2).

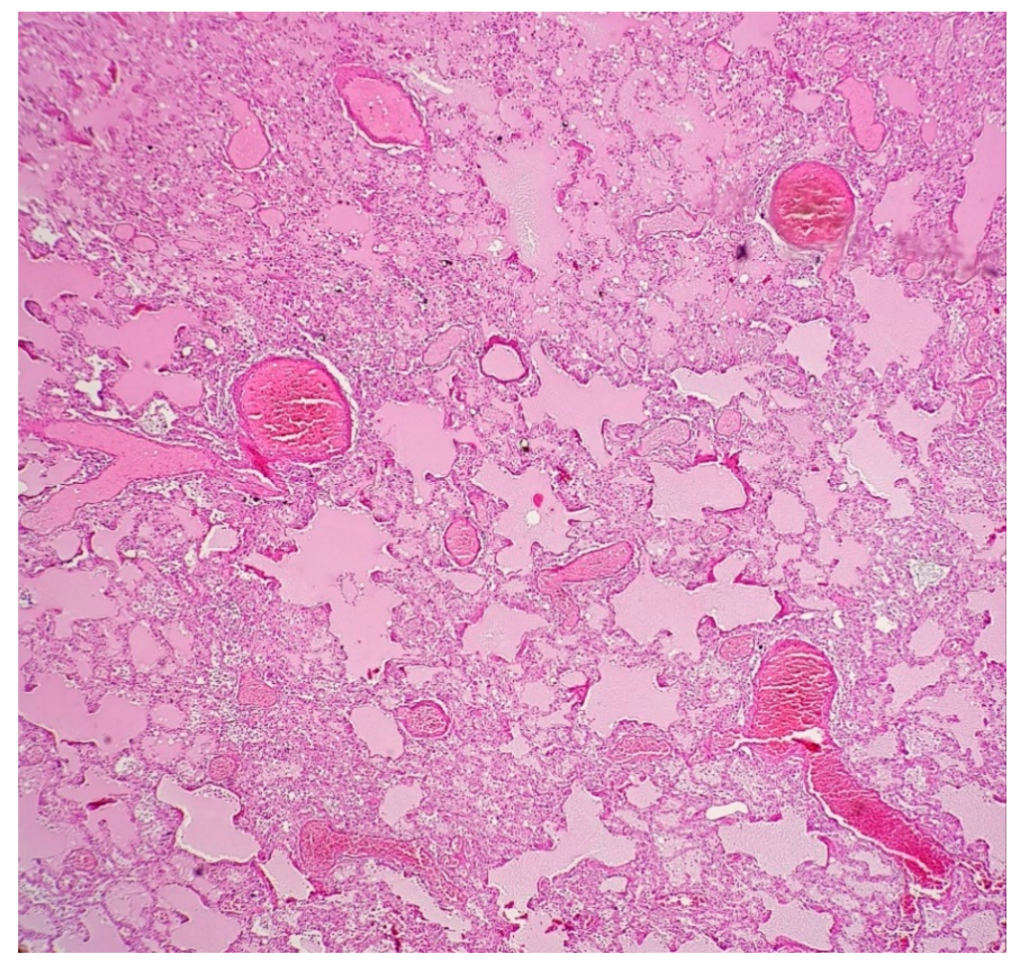

(a)

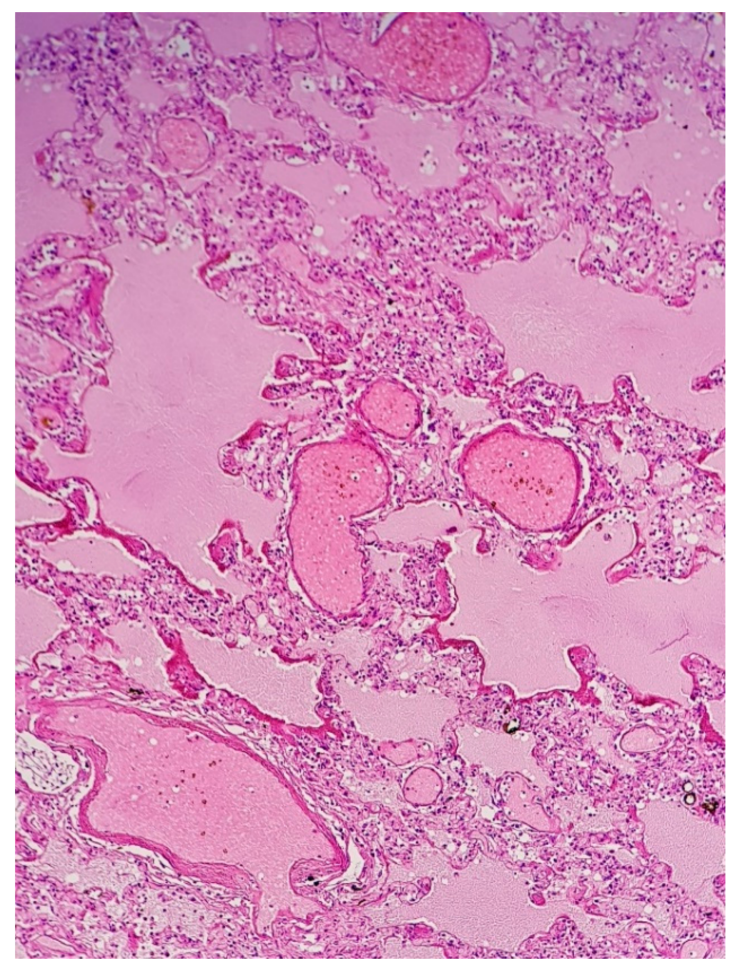

(b)

Figure 2. HE stain of maternal pulmonary tissue: (a) $100 \times$ acute diffuse alveolar damage with massive alveolar edema, hemorrhage, severe vascular stasis, and vascular thrombosis; (b) $400 \times$-infiltration of lung tissue with inflammatory cells, especially in the alveolar septs, along with hyaline membrane formation and fibrin plugs.

Maternal hepatic parenchyma with necrosis (shock liver) and renal parenchyma with decreased glomerular filtration space and accentuated tubular necrosis (shock kidneys) have been observed (Figure 3), as well as uterine leiomyoma and senescent looking placenta with mature villi, inflammatory modifications, and multiple signs of vascular malperfusion (Figure 4).

\subsubsection{Viral RNA SARS-CoV-2 Detection}

Maternal SARS-CoV-2 infection confirmed at admission.

Amniotic fluid and placenta tissue specimens were collected and underwent processing for RT-PCR analysis. Both sources demonstrated positive SARS-CoV-2 genome expression.

\subsection{Case Two: In Utero Fetal Demise with Living Confirmed COVID-19 Mother}

A 27-year-old Caucasian woman, 29-weeks pregnant, gesta 3 para 2, with a known history of type I diabetes mellitus, presented to the emergency department, complaining of nausea, vomiting, loss of appetite, and intense abdominal pain. Upon admission, the patient had discontinued insulin self-administration for 2 days. On clinical examination, the patient presented a blood pressure of $110 / 70 \mathrm{mmHg}$, with a heart rate of 120 beats/minute and blood glucose levels of $195 \mathrm{mg} / \mathrm{dL}$. Laboratory tests revealed an increased white blood cell count $\left(21,100 / \mathrm{mm}^{3}\right)$, urinary ketone bodies, glycosuria, and severe ketoacidosis. On obstetrical exam: absent painful uterine contractions, normal uterine tonus, maintained cervix with intact membranes, and cephalic presentation, but absent fetal movements and absent fetal heartbeat, indicating in utero fetal demise. Caesarean delivery under general 
anesthesia was performed and a female fetus was extracted (APGAR score 0). Maternal nasopharyngeal swabs tested positive for SARS-CoV-2 RNA amplification. Due to the unknown exact cause of fetal demise in accordance with Romanian legislation, a mandatory autopsy was performed.

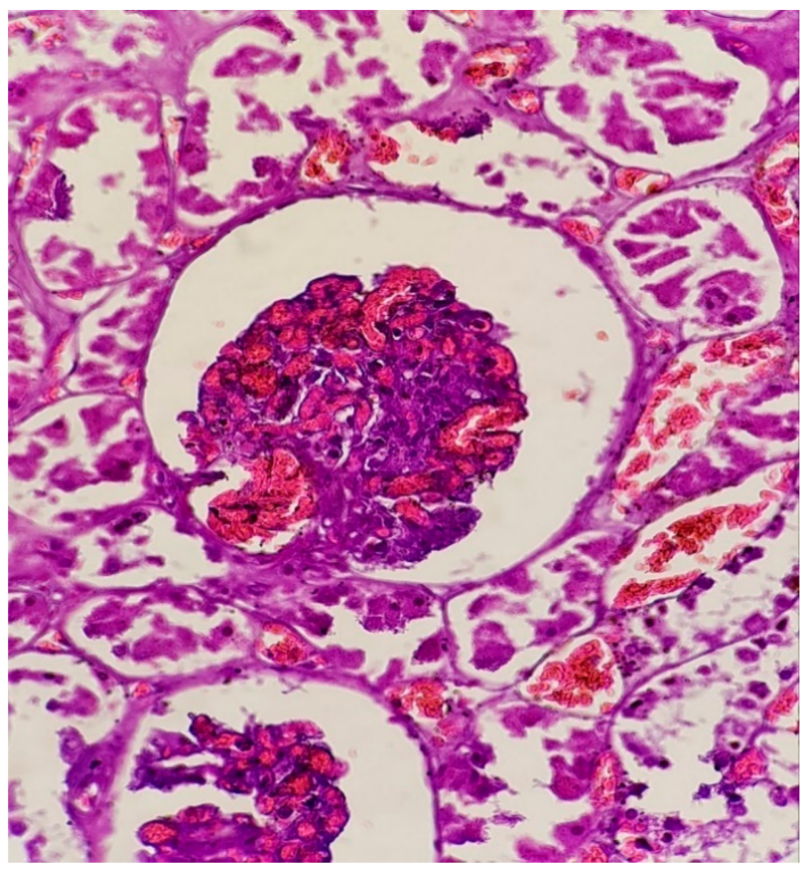

Figure 3. 400 $\times$ HE stain of maternal renal tissue demonstrating distension of glomerular filtration space, capillary loop conglomeration, glomerular stasis, and extensive tubular necrosis, especially in the proximal segments, with extravasated red blood cells.
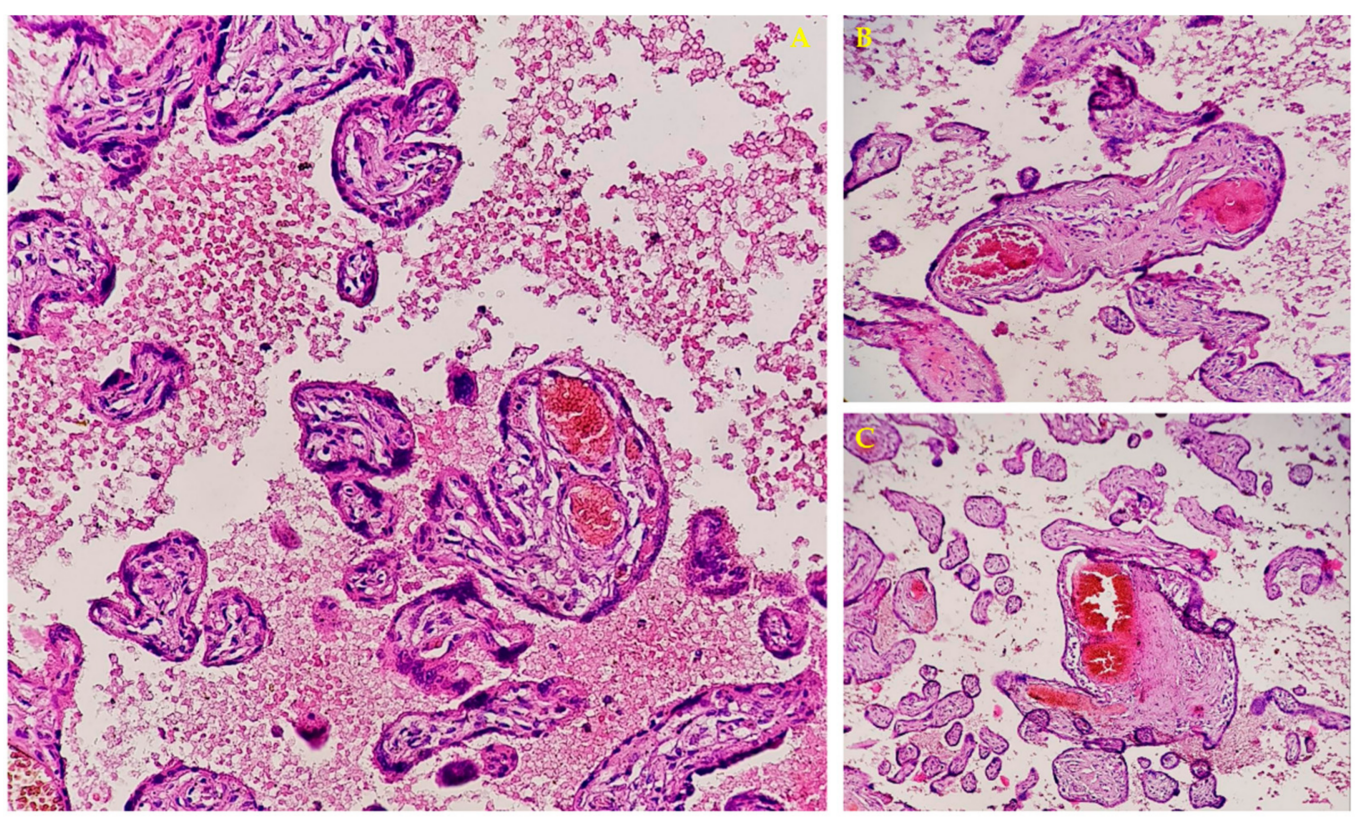

Figure 4. (A) $100 \times$ and (B,C) $400 \times$ HE stain of placenta (second half of gestation period), with vascular stasis and recent thrombi, lacking signs of endothelial activation, minimal inflammatory infiltrate, perivillous fibrin, and increased syncytial knotting.

\subsubsection{Relevant Autopsy Findings}

External examination of the body: 29-week-old fetus, weight $900 \mathrm{~g}$, height $39 \mathrm{~cm}$, cranial perimeter $26 \mathrm{~cm}$, thoracic perimeter $24 \mathrm{~cm}$, and abdominal perimeter $22 \mathrm{~cm}$. The 
fetus presents epidermal desquamation on the lower limbs. The skin is reddish, covered with lanugo, blood, and vernix caseosa. The placenta weighed $300 \mathrm{~g}$ and the umbilical cord was centrally inserted, with a length of $22 \mathrm{~cm}$.

Internal examination of the body: pale-brown lungs with increased consistency, and multiple subpleural petechiae. Upon palpation, absent crepitations. On the section surfaces, low-volume leakage of liquid blood was present.

\subsubsection{Microscopic Findings}

Leptomeningeal hemorrhage, with severe edema in the cerebellar cortex and perivilosity blood suffusions in the intraventricular choroid plexus. Non-aerated lung tissue with partially enlarged alveoli, lined with cubic alveolocytes with a round nucleus, stasis in the interstitial vessels and in the interseptal capillaries, with autolytic bronchial mucosa fragmentation, perivascular blood suffusions, bile pigments, and intra-alveolar amniotic aspirate. Senescent-looking placenta, with small chorionic villi, predominantly lined with syncytial epithelium, capillaries stasis with intra- and inter-villous fibrinoid deposits.

\subsubsection{Viral RNA SARS-CoV-2 Detection}

Maternal SARS-CoV-2 infection confirmed at admission.

Placental tissue specimens were collected and underwent processing for RT-PCR analysis, demonstrating positive SARS-CoV-2 genome expression.

\subsection{Case Three: 2-Month-Old Infant Death with Confirmed COVID-19 Caregivers}

A 2-month-old, male, suckling, third child of the family, born with a weight of $3650 \mathrm{~g}$ and a height of $51 \mathrm{~cm}$, with a favorable postnatal evolution and recent normal routine pediatric check-up, is found dead. The night prior to the event, the child was breastfed at 01:00 a.m. At 07:00 a.m., the mother found him apneic, with yellowish secretions at the nostrils, which turned reddish after the mother's attempt to pat the baby's back. After wiping the secretions, the leakage stopped. Purplish spots (livor mortis) had, allegedly, already appeared on the left side of the child's body. Due to the unknown exact cause of death, in accordance with Romanian legislation, a mandatory autopsy was performed.

\subsubsection{Relevant Autopsy Findings}

External examination of the body: a 2-month-old male infant, with a weight of $5500 \mathrm{~g}$, a height of $60 \mathrm{~cm}$, cranial perimeter $40 \mathrm{~cm}$, thoracic perimeter $38 \mathrm{~cm}$, and an abdominal perimeter of $40 \mathrm{~cm}$, with testicles present in the scrotum. Purple-reddish lividities, in the imbibition phase, are observed on the dorsal side of the body and on the anterior and superior thorax (Figure 5).

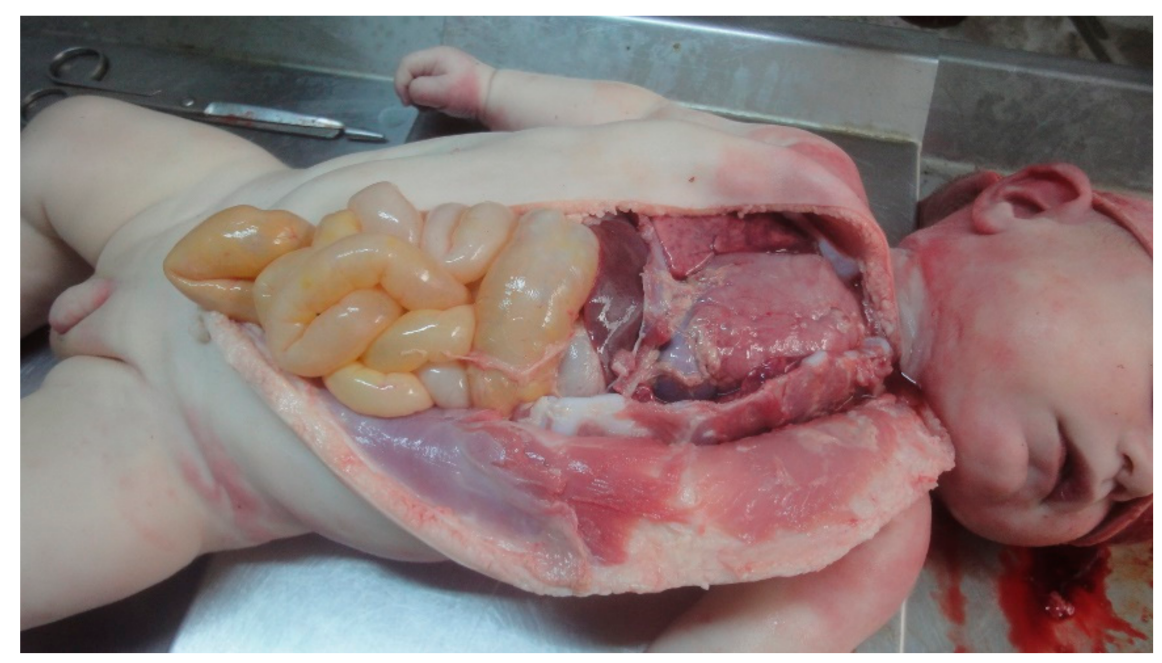

Figure 5. Autopsy aspects of case three. 
Internal examination of the body: purple-brownish lungs, with increased consistency and multiple subpleural petechiae, disseminated bilaterally (Figure 6a). Upon examination, crepitations were present, and on the section surfaces low-volume leakage of liquid blood was present. During the hydrostatic test, larger and smaller fragments of lung partially floated in water. A free pericardial cavity was observed, with epicardial, disseminated petechiae. The heart measured $5 / 3.5 / 2.5 \mathrm{~cm}$ and the cavities contained traces of liquid blood. The myocardium was pale-brownish, with a normal consistency and a width of $0.3 \mathrm{~cm}$ at the right ventricle and $0.6 \mathrm{~cm}$ at the left ventricle, displaying multiple areas of macroscopically visible thrombosis (Figure 6b).

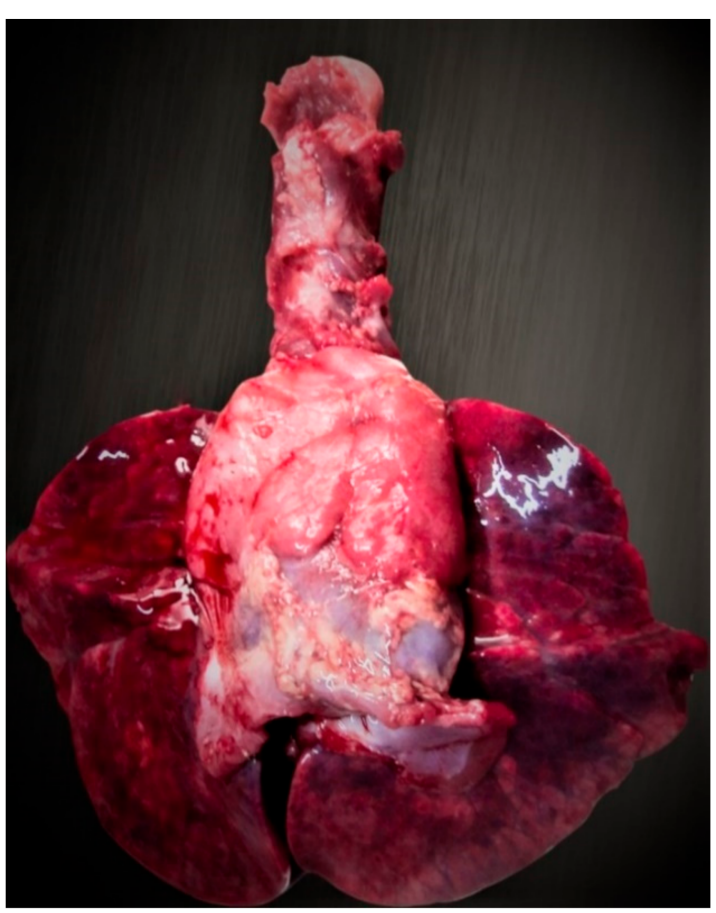

(a)

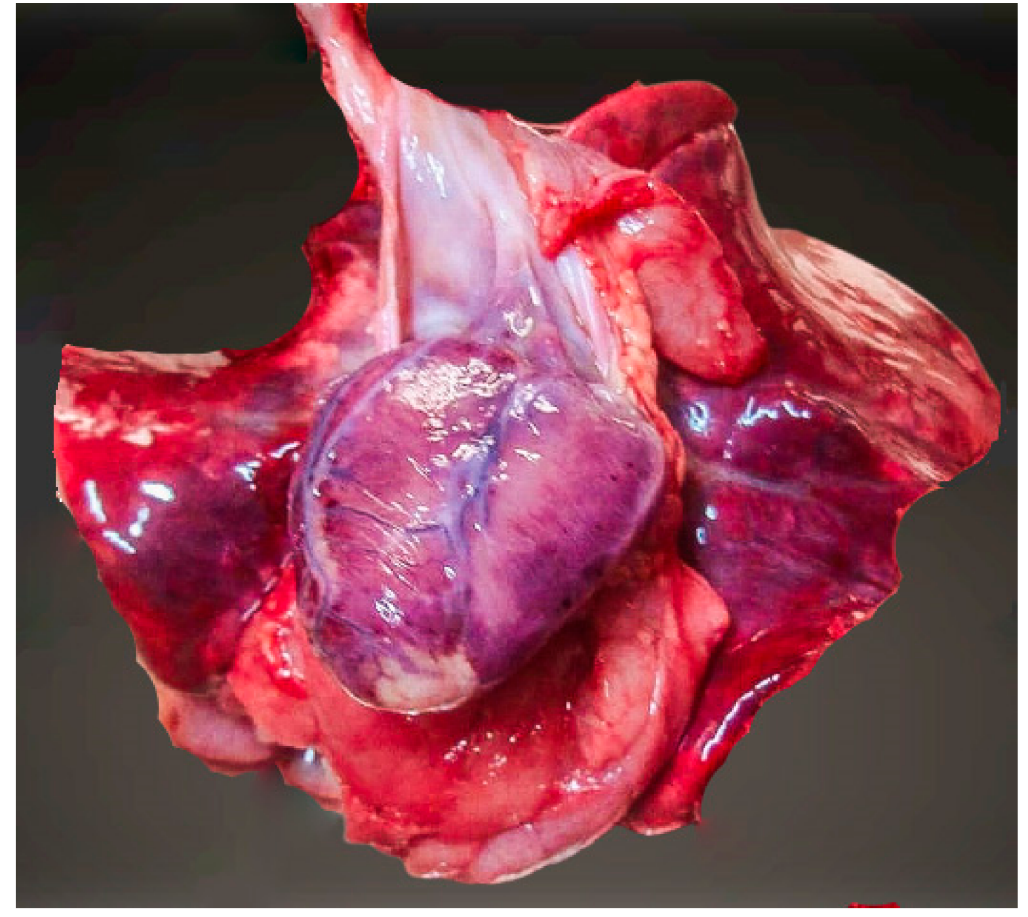

(b)

Figure 6. Infant cardiopulmonary system: (a) Overview: purple-brownish lungs, with multiple subpleural petechiae and increased consistency. (b) Close-up: opened pericardium, multiple macroscopically visible areas of thrombosis in the myocardium.

\subsubsection{Microscopic Findings}

Cardiac microthrombosis (Figure 7), diffuse, sero-catharal pneumonia, suggestive of an interstitial viral lesion (Figure 8a,b) and leptomeningeal hemorrhage, with edema in the cerebellar cortex.

\subsubsection{Viral RNA SARS-CoV-2 Detection}

Infant pulmonary tissue specimens were collected and underwent processing for RTPCR analysis, demonstrating positive SARS-CoV-2 genome expression. Further case investigation revealed that the infant had SARS-CoV-2-positive caregivers (multiple family members). 


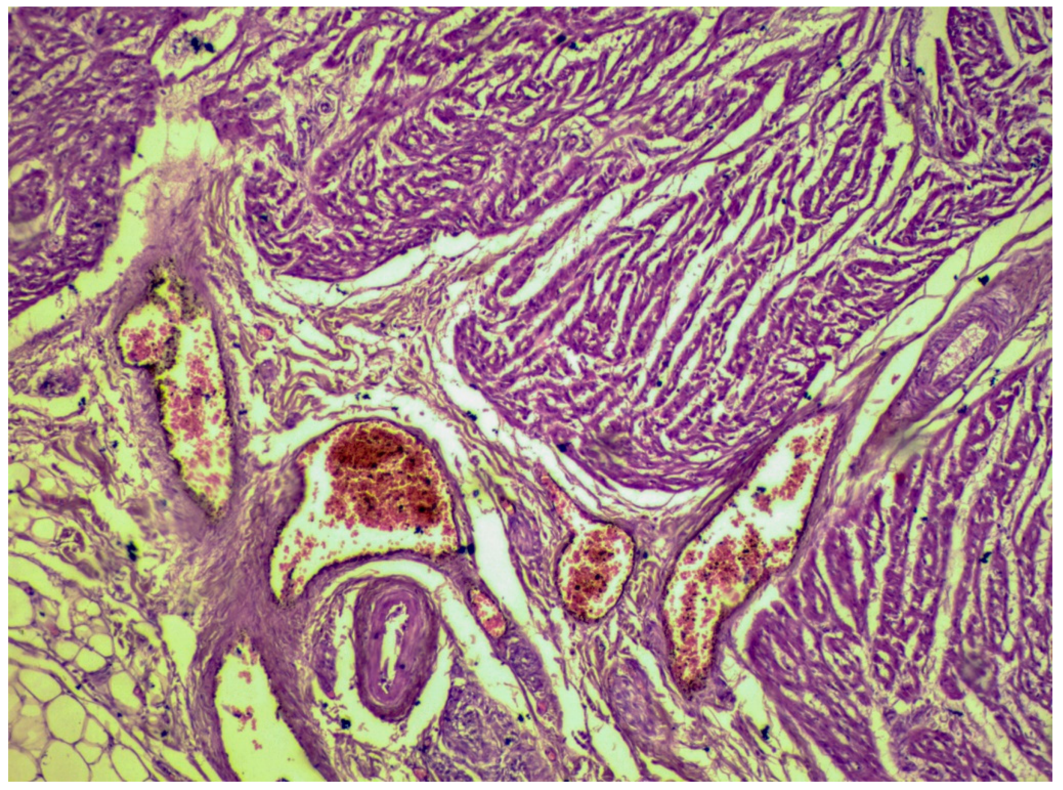

Figure 7. 400 $\times$ HE stain of fetal cardiac tissue demonstrating microthrombosis.

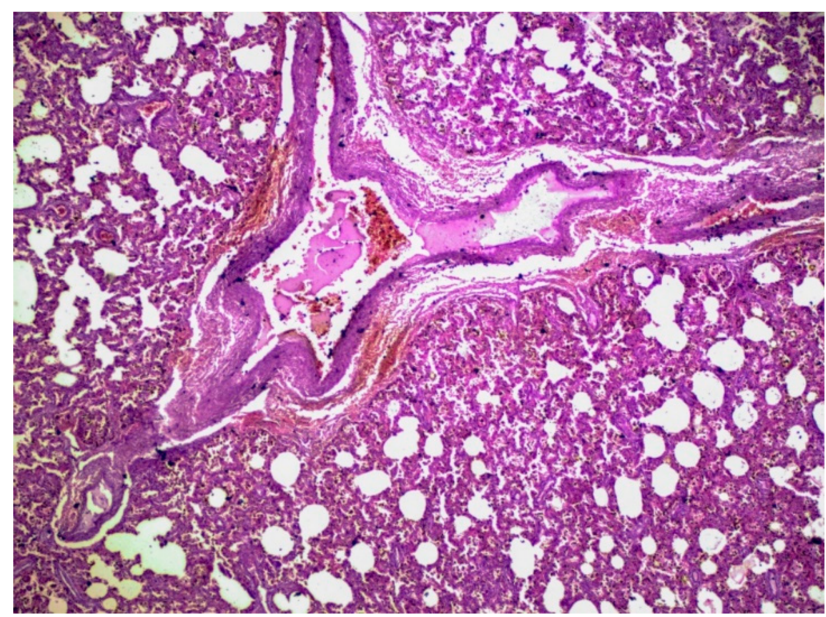

(a)

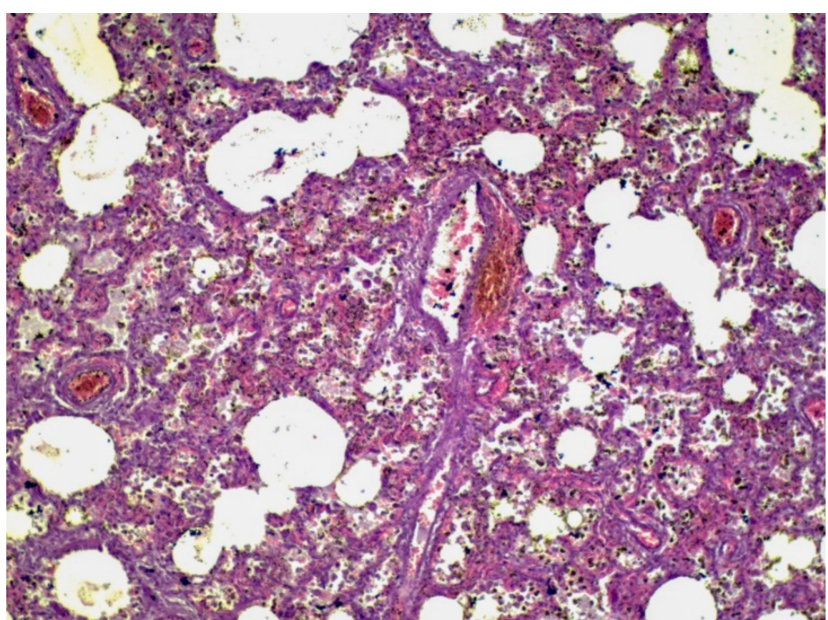

(b)

Figure 8. HE stain of infant pulmonary tissue, suggestive of viral interstitial lesion: (a) $100 \times$ 一 severe vascular stasis and thick alveolar septs; (b) $400 \times$ — vascular thrombosis, infiltration of lung tissue with inflammatory cells, especially in the thick alveolar septs.

\section{Discussion}

Vertical transmission of SARS-CoV-2 is, fortunately, a rare clinical occurrence, yet the risk of mothers-to-be passing on the virus to their unborn fetuses is still an evolving area of research. Although initial reports on SARS-CoV-2 vertical transmission found no evidence to support its occurrence in small sample sizes [65-67], these results remain controversial. Later investigations supported the notion of vertical transmission based on serological evaluations of RT-PCR-positive newborns (high levels of SARS-CoV-2-targeted IgM and inflammatory cytokines-IL6/IL10 [68-73]), amniotic fluid [70], and cord blood RT-PCR [74]. Recently, documentation of the SARS-CoV-2 genome on both sides of the placenta, maternal and fetal, apparently demonstrated transplacental transmission of SARSCoV-2 [45]. Moreover, beyond placental studies, SARS-CoV-2 RNA has been identified in fetal circulating mononuclear cells [75], neonatal blood [73], and in needle aspiration fetal lung biopsies [76]. Most compellingly, SARS-CoV-2 N protein and RNA, as well as viral replication, have been very recently documented in the placenta and fetal tissue samples 
(lung and kidney), resulting from a miscarriage, in the setting of early pregnancy (13 weeks) with maternal SARS-CoV-2 infection, supporting not only in utero transmission but also the notion that fetal organs represent targets for SARS-CoV-2 [77].

Since first being brought to the attention of the scientific community, the definition of in utero transmission of SARS-CoV-2 has dynamically changed, in order to integrate emerging data.

Previous publications have attempted to define unequivocal criteria for materno-fetal, in utero transmission, based on:

1. Identification of the SARS-CoV-2 viral genome in the placenta or amniotic fluid, prior to the onset of labor;

2. Identification of the SARS-CoV-2 viral genome in umbilical cord blood or neonatal blood/respiratory samples/bodily fluids;

3. Documentation of viral particles in fetal/placental tissues, using electron microscopy, immunohistochemistry (IHC), or in situ hybridization [78,79].

Regarding the clinical scenario of intrauterine fetal demise/stillbirth, viral genome detection by RT-PCR or viral particle detection by electron microscopy, in fetal or placental tissue, or viral growth in fetal/placental tissue cultures, corroborated with the maternal prebirth infectious status, have been considered sufficient confirmatory criteria of congenital SARS-CoV-2 infection [80].

Following these classifications, our study confirms materno-fetal in utero transmission of SARS-CoV-2 in two distinct cases, both involving in utero fetal demise: case one, maternal death with concomitant fetal demise, and case two, fetal death as a consequence of maternal illness. Furthermore, for case three, infant demise due to SARS-CoV-2 transmission in the late postpartum context ( 2 months) has been undoubtedly confirmed through lung tissue RT-PCR.

Conversely, SARS-CoV-2 RT-PCR assays, by definition, only indicate the presence of the viral genome in the evaluated sample, without offering any insight into the replicative status of the virus, meaning that, in a clinical setting, a single positive RT-PCR neonatal respiratory sample may only indicate neonatal contamination with viral fragments, acquired during passage through the birth canal, or from the immediate postnatal environment, as opposed to actual neonatal infection [78]. In order to differentiate between contamination and infection, viral detection in a sample, collected from an otherwise sterile source (i.e., neonatal blood, lower respiratory tract samples, or cerebrospinal fluid), is preferred, as opposed to more superficial, non-sterile (neonatal nasopharyngeal swab, saliva, or stool), which are more likely to represent transient contamination [49].

Umbilical cord blood samples have proven to be relatively unreliable, as crosscontamination with maternal blood is frequent (through incorrect sample collection, due to maternal blood cells entering the fetal circulation through the placenta during pregnancy or, more frequently, maternal blood cells entering the fetal circulation during labor as a result of uterine contractions), requiring confirmation follow-up testing for diagnosis (fetal/neonatal peripheral blood sample or other sterile/non-sterile sample) [81].

In evaluating placental tissue, sampling is also a main concern. Although during a caesarean section both the placenta and fetus are delivered under sterile conditions, thus being, theoretically, less prone to contamination than through a vaginal birth [49], the significant exposure to maternal blood during surgery may constitute a concern, especially in severe cases, with the possibility of maternal viremia. Even so, surface placental RTPCR from a caesarean birth is less likely to be false-positive than a vaginal birth sample. Therefore, the results presented for case two, where placental specimens were obtained through an emergency cesarean with in utero fetal demise, seemingly present a high degree of specificity. This was even more the case for case one, where placental and amniotic fluid specimens were obtained via autopsy, after maternal-fetal demise, additionally reducing the risk of contamination due to the lack of active maternal circulation.

This being said, the value of RT-PCR-positive placental and amniotic samples as absolute, confirmatory, diagnostic arguments for congenital SARS-CoV-2 infection in neonates 
has become questionable. In light of recent evidence, regarding inexact correlations between positive RT-PCR placental/amniotic fluid samples and corresponding fetal/neonatal RT-PCR assays [70,82-84], these investigations are no longer viewed as sufficient for the definitive confirmation of in utero transmission of SARS-CoV-2. In the case of fetal demise, in the absence of an additional positive fetal tissue evaluation, these determinations maintain absolute diagnostic value solely for maternal infection [49]. Still, they remain highly suggestive and central arguments for in utero SARS-CoV-2 transmission, especially in the postmortem, autopsy sampling context. Even so, following the latest classification released by $\mathrm{WHO}$, the two cases of in utero SARS-CoV-2 transmission documented in this study fall under the category of possible in utero SARS-CoV-2 infection [49], due to the lack of fetal tissue RT-PCR/IHC evaluation. We aim to follow-up this study with further IHC investigations on the fetal tissues available, in order to remove any doubts regarding the notion of in utero SARS-CoV-2 transmission.

In both cases of fetal demise presented, it is very likely that maternal pre-existing comorbidities played an important role. Although the relationship between SARS-CoV-2 severity and diabetes mellitus is not clearly understood, it has frequently been incriminated as a risk factor for the development of severe forms of SARS-CoV-2. Moreover, in the case of diabetic pregnancies and concomitant COVID-19, the prognosis, for both mother and fetus, seems to be intricately linked with occult, underlying mechanisms, such as a simplified viral uptake by ACE2, a higher basal value of pro-inflammatory cytokines, and being hypoxemic, as well as platelet activation, embolism, and pre-eclampsia [85,86]. Other documented risk factors for poor outcomes in pregnant women infected with SARS-CoV-2 are high body mass index (BMI), and maternal age over 35 [21].

Obesity in pregnancy represents a risk factor for both thromboembolism and severe COVID-19. All factors of the classic Virchow triad are met during the course of COVID-19 and contribute synergically to the risk of thromboembolic events: hemodynamic changes (increased blood viscosity due to elevated fibrinogen, but also blood stasis due to hospitalization and immobilization); hypercoagulability (due to an overwhelming inflammatory state, occurring early after infection); and endothelial injury/dysfunction (ACE2 receptor expression on endothelial cells allows viral entry and cytopathic effects-endotheliosis). Additionally, pregnancy acts upon these pro-thromboembolic factors independently: mechanical venous compression due to gravid uterus volume increase; progesterone-induced loss of venous wall tonus; and endothelial monolayer breakdown due to circulating cytokines and growth factors. Overall, hypercoagulability increases in pregnancy by five-fold, culminating in the late gestation period, being partly explained by, and well-reflected in, the highly significant rise in D-dimer levels from the first to the third trimester. Moreover, obesity implies chronic pre-existing impairment of endothelial function (secondary to increased production of inflammatory T helper cell 2 cytokines), but also an altered antiviral immune response, as suppressors of cytokine signaling are upregulated and type I and III interferon responses are delayed and blunted, leading to ineffective viral clearance, while high circulating levels of adipocyte-secreted pro-inflammatory leptin have been associated with more severe respiratory disease $[87,88]$.

The underlying mechanisms of the association between COVID-19 and pre-eclampsia remain unclear, although some data suggest SARS-CoV-2 infection may induce dysfunction of the renin-angiotensin system and, consequentially, vasoconstriction by activating ACE2 receptors [89]. Still, systematic endothelial dysfunction, as a causal mechanism of preeclampsia, most likely shares a common pathway with COVID-19 illness, an idea supported by findings regarding non-pregnant patients with severe COVID-19 who developed clinical manifestations similar to pre-eclampsia, but distinguishable by biomarker levels (i.e., serum-soluble fms-like tyrosine kinase 1 and placental growth factor) [90]. Another stipulated perspective is that SARS-CoV-2 infection, due to its pro-inflammatory implications, determines systemic endothelial dysfunction and, subsequently, pre-eclampsia [91,92]. Additionally, besides pre-eclampsia as a risk factor, preterm birth and other adverse perinatal outcomes (stillbirth, IUGR) seen in severe COVID-19 could be directly linked to exagger- 
ated systemic inflammatory responses, which create a suboptimal environment for fetal growth and development, by entertaining endothelial dysfunction and hypercoagulability at the level of the maternal-fetal interface, a mechanism supported by histological findings of placental fetal vascular malperfusion in patients with COVID-19 at delivery [93]. Preterm delivery still represents the main complication of COVID-19 in pregnancy, while emerging data also indicate increased risk for other problematic, adverse outcomes-pre-eclampsia, stillbirth, and higher rates of neonatal intensive care unit admissions-implying an urgent need for evidence to guide clinical decision-making, in order to minimize maternal, fetal, and neonatal morbidity as well as mortality [23].

For case one, the pregnancy was high-risk to begin with (39-year-old, diabetic, and obese mother with gestational hypertension). These high-risk factors for pregnancy outcome are also involved in the development of severe forms of COVID-19. The mother became infected with SARS-CoV-2 in the third trimester and developed a severe form, most likely with circulating viremia, which in turn lead to the in utero transmission of the infection. Fetal demise seemingly occurred slightly before maternal death, or concomitantly. In any case, COVID-19 was an important contributor.

For case two, a maternal history of type 1 diabetes mellitus was documented, and third trimester fetal demise occurred in utero, before the diagnosis of SARS-CoV-2 infection. This raises questions regarding the traditional paradigm of hematogenous vertical transmission, which requires circulating viremia to occur. The mother did not develop a severe form of SARS-CoV-2, so it is very unlikely that viremia occurred, yet the fetus became infected regardless.

It has been established that pregnant women are more susceptible to respiratory pathogens; therefore, they may be more susceptible to COVID-19 infection than the general population [16]. Furthermore, pregnancy represents a modulated immune condition [94] caused by multiple cellular and humoral physiological adaptations necessary for fetal development, while maintaining an adequate immune response against invading microorganisms [16], creating a very unique maternal immune response to environmental aggression [18]. Immune cell accumulation in the decidua and among trophoblastic cells (mainly macrophages, natural killer cells, and regulatory T cells), especially during the first trimester, provides a protective effect, preventing abortion of the semi-allogeneic fetus [94,95]. From a hormonal perspective, first-trimester estrogen and progesterone level fluctuations cause reversible thymus degeneration, with decreased T-cell (CD4+/CD8+) count and activity, contributing to a greater susceptibility to infections during pregnancy [96]. Sustained progesterone secretion also prevents fetal detection as a non-self-antigen.

Moreover, the characteristic pro-inflammatory state associated with the first and third trimesters of pregnancy may determine an additional severe inflammatory response in the case of an overlapping SARS-CoV-2-induced cytokine storm [18]. Viral-infectionrelated maternal inflammation may affect fetal brain development and lead to a wide range of neuronal and behavioral phenotype dysfunctions [97]. Additionally, ACE2 viral receptor hyper-expression during pregnancy, although contributing to efficient blood pressure regulation, may also favor host cell permissiveness for SARS-CoV-2 entry [96] which, in turn, implies a higher risk of complications from SARS-CoV-2 infection [38]. Conversely, the trophoblast is able to detect external aggressors (bacteria and viruses) via pattern-recognition receptors (PRRs), determining cytokine release, mainly interferons, with significant antiviral and immunomodulatory effects $[95,98]$. Active transplacental transport of maternal IgG antibodies after 16 weeks of pregnancy may improve fetal immunity against viral aggression [95].

Individual immune responses are the cardinal element behind SARS-CoV-2 infection progression. After the viral genome is released into the host cytosol, SARS-CoV-2 viral replication begins. Aberrant RNA sequences, byproducts of replication, will, in turn, be detected by intracellular receptors which activate the cellular antiviral response, involving enhanced leukocyte chemotaxis and transcriptional induction of type I and 
III interferons (IFN-I/-III), followed by the subregulation of IFN-stimulated genes [18]. Lung cell damage activates a local immune response, resulting in monocyte/macrophage recruitment [99], while chemokines induce specific leukocyte subset recruitment and coordination [100]. Circulating immune cell relocation in the pulmonary tissue will determine additional cytokine/chemokine production, while also creating multiple imbalances in immune cell populations-increased leukocyte count and neutrophil-lymphocyte ratio, with decreased lymphocytes (especially T cells [101]), thus setting the scene for immune response dysregulation.

The relationship between SARS-CoV-2 infection and extensive activation of inflammation signaling pathways has been well-documented, representing the main immunopathological mechanism through which severe forms occur in susceptible individuals. Due to the infection, a dysfunctional immune response takes place (i.e., CRS), characterized by high circulating levels of interleukin (IL)-1 $\beta$, IL-1RA, IL-2, IL-6, IL-7, IL-8, IL-9 IL10, interferon gamma-induced protein 10 (CXCL10), monocyte chemoattractant protein1 (CCL2), macrophage inflammatory protein $1 \alpha$ (CCL3) and $1 \beta$ (CCL4), granulocyte colony-stimulating factor, and tumor necrosis factor $\alpha[18,34,99,102-105]$, which mediate widespread lung inflammation in an attempt to eradicate the pathogen. Concomitantly, these inflammatory status modifications interfere with the coagulation cascade in an attempt to keep the infection localized through pulmonary capillary microthrombosis. Fibrinolysis is diminished via IL-6 trans-signaling-induced vascular endothelial cell production of plasminogen activator inhibitor-1 (PAI-1) [106], while clotting is facilitated through complement-induced coagulopathy [107]. Overall, these alterations have proven to be incapable of controlling pathogen dissemination while producing severe adverse effects in the infected host body (i.e., ARDS, DIC, and finally multiple systems organ failure $[104,108])$.

Pulmonary endothelial cell dysfunction seems to play a cardinal role in the onset and progression of ARDS [109,110], the main cause of mortality in COVID-19 [111]. Physiologically, pulmonary endothelial cells are surrounded by pericytes, which have the ability to limit inflammation by restricting immune cell entry and prevent coagulation via the expression of anticoagulant factors; when this endothelial barrier is damaged, tissue edema, excessive inflammation, and hypercoagulability ensue, i.e., the basis for ARDS [14]. The risk factors for severe COVID-19 (advanced age, obesity, diabetes mellitus, and cardiovascular disease) are all associated with endothelial cell dysfunction as well [112].

From a clinical perspective, in COVID-19, pulmonary involvement is usually bilateral, consisting of extensive interstitial and alveolar inflammatory infiltrates, thickening of alveolar septa, vascular congestion, and lung edema, which, in turn, may lead to pulmonary fibrosis [113]. In the case of pregnant women, these modifications occur over an already existing background of physiological alterations which hinder respiratory function (thorax shape modifications and diaphragmatic elevation, decrease in total lung capacity, as well as functional residual capacity, end-expiratory volumes, and residual volumes from early in pregnancy) [14].

As a consequence of lung parenchymal damage and altered pulmonary circulation, pulmonary hypertension may develop, leading to right ventricular involvement and right heart failure [113], putting additional strain on the maternal cardiovascular system and possibly influencing outcomes. Other pathophysiological mechanisms determining cardiovascular impairment in COVID-19 and raising concerns regarding maternal outcomes are as follows: direct viral injury of cardiomyocytes, multiple inflammatory responses triggered in the context of cytokine release syndrome (CRS), destabilization of existing coronary plaques, coagulopathy leading to pulmonary thromboembolism [114], or microthrombogenesis, often aggravated by hypoxemia, with reports of persistent, post-COVID19 diastolic dysfunction and alterations of left ventricular systolic function in previously healthy patients $[115,116]$.

Maternal pathological findings, for case one, exemplify the aforementioned pathophysiological substrate, which seemingly affects all essential organ systems. As expected, 
the main modifications were pulmonary. Migration of lymphocytes and macrophages in the lungs results in interstitial damage, which impedes physiological gas exchange and compromises oxygenation, manifesting clinically as hypoxemia and dyspnea $[18,117]$. Consistent with previous reports, a non-specific inflammatory response (intense infiltration and edema) $[117,118]$, thickening and damage of the alveolar septa, severe desquamation of alveolar epithelial cells and inflammatory infiltration of the alveolar space, leading to pulmonary hyperplasia and necrosis [119,120], as well as capillary damage [121], have all been documented in maternal lung specimens.

Although cardiac involvement in severe forms of COVID-19 is well-documented [122], comorbidities must also be taken into consideration in evaluating cardiac specimens, as our findings (cardiosclerosis and lipomatosis) are more likely to be chronic in nature, as opposed to more acute modifications, which have previously been reported (pericarditis and inflammatory cells infiltrating adventitia) in cases without pre-existing cardiovascular disease [121].

Previous reports have identified acute renal failure in approximately one-third of COVID-19 patients [123], with signs of renal impairment (proteinuria/hematuria/elevated creatinine and blood urea nitrogen) on admission being prevalent and predictive for in-hospital mortality [124]. Pathological examination of renal autopsy specimens from COVID-19 patients with renal impairment revealed varying degrees of acute tubular necrosis, luminal brush border sloughing and vacuole degeneration, severe infiltration of lymphocytes in the tubulo-interstitium, viral-infection-associated syncytia, and dilated glomerular capillary vessels, while IHC documented SARS-CoV-2 N protein expression (mostly tubular) and transmission electron microscopy (EM) detected intracellular virions and virus-like particles [123]. Our findings are similar to these previous reports. It seems that acute renal tubular injury is most likely caused by the direct cytopathic effect of SARS$\mathrm{CoV}-2$ infection and replication on tubular cells, in conjunction with the complex immune responses this process generates [123].

Regarding hepatic involvement, the main pathological findings previously reported on autopsy specimens were sinusoidal congestion and extravasation of red blood cells into the Disse space, associated with congestion of small veins and necrosis [121], similar to our findings. Investigations into other viral infections of the respiratory tract have revealed that, similarly to acute kidney injury, liver injury may be immune-mediated or a result of direct cytopathic damage [125].

The have been a plethora of histopathological modifications described for confirmed SARS-CoV-2-infected placentas. A recent review [79] identified $2 \%$ of cases with normal histology, while structuring the pathological modifications described in the literature as referring to:

- Inflammation (34.7\% of cases) —in order of frequency: chorioamnionitis/subchorionitis, intervillositis, fetal vasculitis/choriovasculitis, vilitis, and deciduitis;

- Maternal vascular malperfusion (37.8\% of cases) —in order of frequency: increased fibrin deposition, infarction, decidual vasculopathy, intervillous/subchorionic thrombosis, accelerated villous maturation, distal villous hypoplasia, and retroplacental hemorrhage;

- Fetal vascular malperfusion (9.2\% of cases) -in order of frequency: villous stromalvascular karyorrhexis, chorangiosis, delayed villous maturation, avascular villi, and thrombi in fetal circulation;

- Others (16.3\% of cases) - in order of frequency: presence of meconium, villous edema, extravillous trophoblasts, subchorionic laminar necrosis, placental accrete, and Hofbauer cell hyperplasia [79].

Our findings regarding microscopic analysis of placental specimens for cases one and two reaffirmed an already established pattern of placental injury related to abnormal uterine perfusion, involving a wide array of pathological changes (accelerated villous maturation, perivillous/intervillous fibrin deposits, decidual vasculopathy, and syncytial knottingTenney-Parker changes, villous infarction, and intervillous thrombosis $[79,126]$. Still, better definitions are needed in order to fully integrate these findings into a clinical context. 
Information in the literature regarding the fetal effects of SARS-CoV-2 infection are quite scarce, being limited to just a few case reports [77,127,128]. In the context of a COVID19-associated, first-trimester (13-week), miscarriage, with positive placental SARS-CoV-2 RT-PCR, a fetal autopsy revealed pathological modifications in multiple organs:

- Heart (endarteritis in small arteries, with CD68+ interstitial inflammatory infiltrate, edema between cardiomyocytes, and ischemic changes, while the pulmonary artery and aorta showed no alterations);

- Lungs (in the pseudoglandular stage of development, with reactive bronchial epithelium and hypercellularity composed of CD68+ inflammatory macrophages-also seen in interstitium and pleura);

- Skeletal muscle (myositis was observed as a mononuclear inflammation between the fascicles of striated muscle cells of the neck, extremities, and diaphragm, causing severe damage in fibers, with apoptotic cells, atrophy, and intercellular edema);

- Kidneys (scattered cellular detritus and mild interstitial inflammation, with enhanced infiltration of CD68+ cells) [77].

Another case involving in utero fetal demise at 28 weeks with transplacental transmission of SARS-CoV-2, documented by positive placental and umbilical cord blood SARS-CoV-2 RT-PCR, demonstrated chronic histiocytic intervillositis, maternal and fetal vascular malperfusion, microglial hyperplasia, and lymphocytic infiltrate in the placenta and fetal tissues, while A macroscopic autopsy evaluation reported skin discoloration and moderate peeling, red serous effusions in the chest and abdomen, petechial hemorrhage in the heart and lungs, hepatic discoloration and friability, and lung and kidney hypoplasia (both < fifth percentile) [127].

Very recently, in a case of in utero fetal demise at 34 weeks, associated with mild maternal COVID-19 and severe placental thromboembolism, SARS-CoV-2 quantitative (q)RT-PCR detected high amounts of viral genome in the placenta (at least one order of magnitude higher than the average for nasopharyngeal swabs, used as positive control), but also in the umbilical cord and in fetal tissues (positive in the salivary gland, trachea, olfactory bulb, lungs, liver, and kidneys, but negative in the heart or brain). Subsequent $S$ protein IHC labeling was positive for the fetal lung, brain, and heart. A macroscopic examination revealed postmortem autolysis (fetal death $>48 \mathrm{~h}$ ) - extensive skin detachment from the surface of the body, thoracic/abdominal organ congestion, with soft consistency, and a brain with wide, congested, and extremely soft gyri. Histologically, the nevrax showed no signs of inflammation or necrosis, while leptomeningeal and choroid plexus $\mathrm{T}$ lymphocyte IHC was negative (slight positive in the olfactory bulb). The pituitary gland showed small calcification foci and the vagus nerve and dorsal root ganglia were normal, as were the skeletal muscles (psoas, diaphragm, and abdominal). Lung histology revealed mild thickening of the pleura and alveolar septa, with mild infiltration of lymphocytes, without signs of fibrosis on Gomori trichrome staining. IHC for leukocyte common antigen (LCA) showed small aggregates of CD3 lymphocytes in the pleura and pulmonary septa and, occasionally, in the renal interstitium. Most of the other organs showed signs of maceration, particularly the liver, adrenal gland, spleen, pancreas, and intestines [128].

For case one, microscopy documented inflammatory and coagulopathic modifications in nevraxial tissues: leptomeningeal vascular microthrombosis, cerebral edema, mild brainstem vascular stasis, and edema in fetal brain tissue fragments. For case two, the same pattern of nevraxial tissue damage is seen, except the thrombotic lesions are replaced by hemorrhagic ones: leptomeningeal hemorrhage, with severe edema in the cerebellar cortex and perivilosity blood suffusions in the intraventricular choroid plexus. Additionally, case two presented significant pulmonary modifications, with the same underlying pathophysiological substrate (inflammation and coagulopathy): non-aerated lung tissue with partially enlarged alveoli, lined with cubic alveolocytes with a round nucleus, stasis in the interstitial vessels and in the interseptal capillaries, with autolytic bronchial mucosa fragmentation, and perivascular blood suffusions. 
Interestingly, for case one, in which the mother had developed a severe form of COVID-19, the fetal impact seems to be less extensive-limited to the nevrax (inflammation and thrombosis) without any pulmonary involvement, whereas for case two the fetal impact seems to be more severe, involving multiple organ systems: extensive pulmonary involvement, with a different type of neurological lesion (hemorrhagic, as opposed to thrombotic). These observations apparently support the idea that, for case one, fetal demise was a consequence of maternal death due to severe COVID-19 while, for case two, fetal demise was a direct consequence of fetal SARS-CoV-2 infection, with the mother finally recovering completely from a moderate form of the disease.

So far, there have been very few articles describing COVID-19 pathology in infants, children, and adolescents, partly due to low incidence/prevalence (1- $8 \%$ of laboratoryconfirmed cases [111,129]), but also because this demographic has the lowest risk of severe COVID-19 progression/complications [130], accounting for $<1 \%$ of the total number of COVID-19 deaths [131]. Usually, most cases are asymptomatic or mild disease, with full recovery occurring within a few weeks of disease onset. Even so, a small fraction will develop severe forms of COVID-19, with dyspnea, cyanosis, and hypoxemia, due to pneumonia and/or ARDS [132], requiring pediatric intensive care unit admission and prolonged ventilation $[129,133]$. The intrinsic pathological substrate allowing for these developments to occur is poorly understood. Even less can be said about rapidly progressing forms of COVID-19 in this age group.

Due to this pleomorphism of clinical presentations in children, since April 2020 both the U.S. Centers for Disease Control and Prevention (CDC) and the WHO have, separately yet similarly, defined a novel, COVID-19-related childhood inflammatory disorder, named multisystem inflammatory syndrome in children (MIS-C), or pediatric inflammatory multisystem syndrome (PIMS) [134-136]. MIS-C usually occurs 2 to 4 weeks after initial SARS-CoV-2 infection, determining critical illness in a minority of patients-pronounced cardiac involvement and coronary-artery aneurysms (10-20\% of cases) [136]. Even so, estimated mortality is low $(2-4 \%)$, with most patients recovering under intensive care support [136].

The pathogenesis of systemic disease and progression of SARS-CoV-2 infection to multiple organ involvement are not fully understood. A recent Brazilian study, the first and largest autopsy series of COVID-19 in children and adolescents (five cases), documented the presence of SARS-CoV-2 in multiple tissues and defined two major patterns for severe forms of the disease in this population: primary pulmonary COVID-19 (SARS-CoV-2 pneumonia, usually associated with pre-existing severe comorbidities, leading to ARDS and death) and a multisystem inflammatory syndrome, involving several organ systems [137]. Endothelial cell injury in COVID-19 is seemingly the main driver of disease pathogenesis, leading to thrombotic events in the pulmonary and systemic circulations, with a plethora of pathological modifications and distinct clinical presentations $[110,138,139]$ :

- Neurological-reactive microglia, edema, endotheliopathy, and disorganization of the blood-brain barrier, translating to encephalopathy, headache, brainstem signs with dysarthria or dysphagia, meningism, cerebellar ataxia [140], and acute encephalopathy with refractory seizures [137];

- Cardiovascular-severe myocarditis with endotheliopathy, diffuse perivascular interstitial inflammatory infiltrate, and cardiac necrosis, leading to cardiac failure (type I tissue response) [141] but also cardiac necrosis and dysfunction in the absence of cardiac inflammation [137];

- Pulmonary—mild pneumonia and microthrombosis [137];

- Hematological—hemophagocytosis, splenitis, lymphoid hypoplasia, and lymphoid depletion, leading to immune dysfunction [137];

- Gastrointestinal - cholestatic hepatitis with hepatocyte syncytial changes and centrilobular hepatic necrosis [142]; colitis with inflammation, smooth muscle damage, and microthrombotic/ischaemic events [137];

- Renal—acute tubular necrosis, glomerular microthrombi $[137,143]$. 
We present the unfortunate case of a 2-month-old infant (case 3) with a harmonious postnatal development undergoing sudden death due to a rapidly progressive, pauci/asymptomatic form of COVID-19. The infant most likely contracted the disease from the infected mother and/or other infected caregivers (horizontal household spread), who were also asymptomatic. SARS-CoV-2 infection was only suspected after the apparently inexplicable death of the infant and subsequent autopsy report, mandating further epidemiological investigation.

Pathological findings for case three demonstrate multisystem involvement (macroscopically apparent cardiac thrombosis; diffuse, sero-catharal, and interstitial viral pneumonia, with severe vascular stasis, thrombosis, thick alveolar septs, and inflammatory infiltration; leptomeningeal hemorrhage, with cerebellar cortex edema), indicating MIS-C, yet diagnosis criteria are not met due to the lack of symptomatology and clinical evaluation. This extremely rapid disease progression in an infant with no pre-existing comorbidities may be indicative of some occult predisposing factors, and may constitute a distinct clinical phenotype.

\section{Conclusions}

In utero transmission of SARS-CoV-2 may occur, albeit rarely, in the context of COVID19 during pregnancy. Beyond the physiological, pregnancy-related modifications, other risk factors, especially advanced maternal age, and pre-existing comorbidities (i.e., diabetes mellitus, obesity, and high blood pressure), may be predictive of unfavorable maternal and fetal outcomes. More research is necessary in order to fully understand the predisposing factors for in utero transmission of SARS-CoV-2.

Fetal and placental lesions due to SARS-Cov-2 in utero transmission are heterogeneous and require better definitions and classifications for clinical practice integration. Inflammation, coagulopathy, and vascular malperfusion seem to be the main pathological substrate.

Although usually benign in infants and children, COVID-19 may present as a multisystem inflammatory syndrome, involving various organs and tissues, in this age group. In this study, we documented an apparently asymptomatic, rapidly progressive and, ultimately, fatal, infantile COVID-19 phenotype, with multisystem involvement. More data are needed in order to confirm these observations.

Author Contributions: Conceptualization, A.E., V.C., C.O.M., R.D., T.G.C., D.N., C.P., A.M., N.A. and M.R.; methodology, A.E., V.C., C.O.M., R.D., T.G.C., D.N., C.P., A.M., N.A. and M.R.; software, T.G.C. and D.N.; validation, A.E., V.C., C.O.M., R.D. and M.R.; formal analysis, A.E., V.C., C.O.M., R.D., T.G.C., D.N., C.P., A.M., N.A. and M.R.; investigation, R.D., T.G.C. and D.N.; resources, A.E., V.C., C.O.M., R.D., A.M. and N.A.; data curation, A.E., V.C., C.O.M., R.D., A.M., N.A. and C.P.; writing-original draft preparation, A.E., V.C., C.O.M., R.D., T.G.C., D.N., C.P., A.M., N.A. and M.R.; writing-review and editing, T.G.C. and D.N.; visualization, A.E., V.C., C.O.M., R.D., T.G.C., D.N., C.P., A.M., N.A. and M.R.; supervision, A.E.; project administration, A.E. and R.D.; funding acquisition-not applicable. All authors have read and agreed to the published version of the manuscript.

Funding: This research received no external funding.

Institutional Review Board Statement: The study was conducted according to the guidelines of the Declaration of Helsinki and approved by the Ethics Committee of the University of Medicine and Pharmacy "Victor Babes" Timisoara (Nr. 29/05.10.2020).

Informed Consent Statement: Informed consent was obtained from all subjects and next of kin involved in the study. Written informed consent has been obtained from the patients and next of kin to publish this paper.

Data Availability Statement: All available data are presented in the manuscript.

Conflicts of Interest: The authors declare no conflict of interest. 


\section{References}

1. Roser, M.; Ritchie, H.; Ortiz-Ospina, E.; Hasell, J. Coronavirus Pandemic (COVID-19). Our World in Data 2020. Available online: https: / / www.ourworldindata.org/covid-cases (accessed on 23 August 2021).

2. World Health Organization. WHO Director-General's Opening Remarks at the Media Briefing on COVID-19. Available online: https:/ / www.who.int/director-general/speeches/detail/who-director-general-s-opening-remarks-at-the-media-briefingon-covid-19---11-march-2020 (accessed on 23 August 2021).

3. Zhu, N.; Zhang, D.; Wang, W.; Li, X.; Yang, B.; Song, J.; Zhao, X.; Huang, B.; Shi, W.; Lu, R.; et al. A Novel Coronavirus from Patients with Pneumonia in China, 2019. N. Engl. J. Med. 2020, 382, 727-733. [CrossRef] [PubMed]

4. Coronaviridae Study Group of the International Committee on Taxonomy of Viruses. The Species Severe acute respiratory syndrome-related coronavirus: Classifying 2019-nCoV and naming it SARS-CoV-2. Nat. Microbiol. 2020, 5, 536-544. [CrossRef] [PubMed]

5. Harrison, A.G.; Lin, T.; Wang, P. Mechanisms of SARS-CoV-2 Transmission and Pathogenesis. Trends Immunol. 2020, 41, 1100-1115. [CrossRef] [PubMed]

6. $\quad$ Song, Z.; Xu, Y.; Bao, L.; Zhang, L.; Yu, P.; Qu, Y.; Zhu, H.; Zhao, W.; Han, Y.; Qin, C. From SARS to MERS, Thrusting Coronaviruses into the Spotlight. Viruses 2019, 11, 59. [CrossRef]

7. Yan, J.; Guo, J.; Fan, C.; Juan, J.; Yu, X.; Li, J.; Feng, L.; Li, C.; Chen, H.; Qiao, Y.; et al. Coronavirus disease 2019 in pregnant women: A report based on 116 cases. Am. J. Obstet. Gynecol. 2020, 223, 111.e1-111.e14. [CrossRef]

8. Schwartz, D.A. An Analysis of 38 Pregnant Women with COVID-19, Their Newborn Infants, and Maternal-Fetal Transmission of SARS-CoV-2: Maternal Coronavirus Infections and Pregnancy Outcomes. Arch. Pathol. Lab. Med. 2020, 144, 799-805. [CrossRef]

9. Jamieson, D.; Honein, M.; Rasmussen, S.; Williams, J.L.; Swerdlow, D.L.; Biggerstaff, M.; Lindstrom, S.; Louie, J.K.; Christ, C.M.; Bohm, S.R.; et al. H1N1 2009 influenza virus infection during pregnancy in the USA. Lancet 2009, 374, 451-458. [CrossRef]

10. Schwartz, D.A. Maternal and Infant Death and the rVSV-ZEBOV Vaccine Through Three Recent Ebola Virus Epidemics-West Africa, DRC Équateur and DRC Kivu: 4 Years of Excluding Pregnant and Lactating Women and Their Infants from Immunization. Curr. Trop. Med. Rep. 2019, 6, 213-222. [CrossRef]

11. Schwartz, D.A. Maternal Filovirus Infection and Death from Marburg and Ravn Viruses: Highly Lethal to Pregnant Women and Their Fetuses Similar to Ebola Virus. IntechOpen 2019. [CrossRef]

12. Schwartz, D.A.; Anoko, J.N.; Abramowitz, S.A. Pregnant in the Time of Ebola: Women and Their Children in the $2013-2015$ West African Epidemic Global Maternal and Child Health; Springer: Berlin/Heidelberg, Germany, 2019.

13. Alvarado, M.G.; Schwartz, D.A. Zika Virus Infection in Pregnancy, Microcephaly, and Maternal and Fetal Health: What We Think, What We Know, and What We Think We Know. Arch. Pathol. Lab. Med. 2016, 141, 26-32. [CrossRef]

14. Wastnedge, E.A.N.; Reynolds, R.M.; Van Boeckel, S.R.; Stock, S.J.; Denison, F.C.; Maybin, J.A.; Critchley, H.O.D. Pregnancy and COVID-19. Physiol. Rev. 2021, 101, 303-318. [CrossRef]

15. Di Renzo, G.C.; Giardina, I. Coronavirus disease 2019 in pregnancy: Consider thromboembolic disorders and thromboprophylaxis. Am. J. Obstet. Gynecol. 2020, 223, 135. [CrossRef]

16. Liu, H.; Wang, L.-L.; Zhao, S.-J.; Kwak-Kim, J.; Mor, G.; Liao, A.-H. Why are pregnant women susceptible to COVID-19? An immunological viewpoint. J. Reprod. Immunol. 2020, 139, 103122. [CrossRef]

17. Mei, C.; Yang, W.; Wei, X.; Wu, K.; Huang, D. The Unique Microbiome and Innate Immunity during Pregnancy. Front. Immunol. 2019, 10, 2886. [CrossRef]

18. Vale, A.J.M.; Fernandes, A.C.L.; Guzen, F.P.; Pinheiro, F.I.; de Azevedo, E.P.; Cobucci, R.N. Susceptibility to COVID-19 in Pregnancy, Labor, and Postpartum Period: Immune System, Vertical Transmission, and Breastfeeding. Front. Glob. Women's Health 2021, 2, 2572. [CrossRef]

19. Savasi, V.M.; Parisi, F.; Patanè, L.; Ferrazzi, E.; Frigerio, L.; Pellegrino, A.; Spinillo, A.; Tateo, S.; Ottoboni, M.; Veronese, P.; et al. Clinical Findings and Disease Severity in Hospitalized Pregnant Women with Coronavirus Disease 2019 (COVID-19). Obstet. Gynecol. 2020, 136, 252-258. [CrossRef]

20. Matar, R.; Alrahmani, L.; Monzer, N.; Debiane, L.G.; Berbari, E.; Fares, J.; Fitzpatrick, F.; Murad, M.H. Clinical Presentation and Outcomes of Pregnant Women with Coronavirus Disease 2019: A Systematic Review and Meta-analysis. Clin. Infect. Dis. 2020, 72, 521-533. [CrossRef]

21. Allotey, J.; Stallings, E.; Bonet, M.; Yap, M.; Chatterjee, S.; Kew, T.; Debenham, L.; Llavall, A.C.; Dixit, A.; Zhou, D.; et al. Clinical manifestations, risk factors, and maternal and perinatal outcomes of coronavirus disease 2019 in pregnancy: Living systematic review and meta-analysis. BMJ 2020, 370, m3320. [CrossRef]

22. Ahlberg, M.; Neovius, M.; Saltvedt, S.; Söderling, J.; Pettersson, K.; Brandkvist, C.; Stephansson, O. Association of SARS-CoV-2 Test Status and Pregnancy Outcomes. JAMA 2020, 324, 1782. [CrossRef]

23. Wei, S.Q.; Bilodeau-Bertrand, M.; Liu, S.; Auger, N. The impact of COVID-19 on pregnancy outcomes: A systematic review and meta-analysis. Can. Med. Assoc. J. 2021, 193, E540-E548. [CrossRef]

24. Perlman, S.; Netland, J. Coronaviruses post-SARS: Update on replication and pathogenesis. Nat. Rev. Genet. 2009, 7, 439-450. [CrossRef]

25. Laza, R.; Musta, V.F.; Nicolescu, N.D.; Marinescu, A.R.; Mocanu, A.; Vilceanu, L.; Paczeyka, R.; Cut, T.G.; Lazureanu, V.E. Cutaneous Manifestations in SARS-CoV-2 Infection-A Series of Cases from the Largest Infectious Diseases Hospital in Western Romania. Healthcare 2021, 9, 800. [CrossRef] 
26. Zhou, P.; Yang, X.-L.; Wang, X.-G.; Hu, B.; Zhang, L.; Zhang, W.; Si, H.-R.; Zhu, Y.; Li, B.; Huang, C.-L.; et al. A pneumonia outbreak associated with a new coronavirus of probable bat origin. Nature 2020, 579, 270-273. [CrossRef] [PubMed]

27. Wu, F.; Zhao, S.; Yu, B.; Chen, Y.-M.; Wang, W.; Song, Z.-G.; Hu, Y.; Tao, Z.-W.; Tian, J.-H.; Pei, Y.-Y.; et al. A new coronavirus associated with human respiratory disease in China. Nature 2020, 579, 265-269. [CrossRef]

28. Hoffmann, M.; Kleine-Weber, H.; Schroeder, S.; Krüger, N.; Herrler, T.; Erichsen, S.; Schiergens, T.S.; Herrler, G.; Wu, N.-H.; Nitsche, A.; et al. SARS-CoV-2 Cell Entry Depends on ACE2 and TMPRSS2 and Is Blocked by a Clinically Proven Protease Inhibitor. Cell 2020, 181, 271-280.e8. [CrossRef]

29. Jia, H.P.; Look, D.C.; Shi, L.; Hickey, M.; Pewe, L.; Netland, J.; Farzan, M.; Wohlford-Lenane, C.; Perlman, S.; McCray, P.B. ACE2 Receptor Expression and Severe Acute Respiratory Syndrome Coronavirus Infection Depend on Differentiation of Human Airway Epithelia. J. Virol. 2005, 79, 14614-14621. [CrossRef] [PubMed]

30. Hamming, I.; Timens, W.; Bulthuis, M.; Lely, A.; Navis, G.; van Goor, H. Tissue distribution of ACE2 protein, the functional receptor for SARS coronavirus. A first step in understanding SARS pathogenesis. J. Pathol. 2004, 203, 631-637. [CrossRef]

31. Kuba, K.; Imai, Y.; Rao, S.; Gao, H.; Guo, F.; Guan, B.; Huan, Y.; Yang, P.; Zhang, Y.; Deng, W.; et al. A crucial role of angiotensin converting enzyme 2 (ACE2) in SARS coronavirus-induced lung injury. Nat. Med. 2005, 11, 875-879. [CrossRef]

32. Ziegler, C.G.; Allon, S.J.; Nyquist, S.K.; Mbano, I.M.; Miao, V.N.; Tzouanas, C.N.; Cao, Y.; Yousif, A.; Bals, J.; Hauser, B.; et al. SARS-CoV-2 Receptor ACE2 Is an Interferon-Stimulated Gene in Human Airway Epithelial Cells and Is Detected in Specific Cell Subsets across Tissues. Cell 2020, 181, 1016-1035.e9. [CrossRef]

33. Sun, K.; Gu, L.; Ma, L.; Duan, Y. Atlas of ACE2 Gene Expression in Mammals Reveals Novel Insights in Transmisson of SARS-Cov-2. BioRxiv 2020. [CrossRef]

34. Shulla, A.; Heald-Sargent, T.; Subramanya, G.; Zhao, J.; Perlman, S.; Gallagher, T. A Transmembrane Serine Protease Is Linked to the Severe Acute Respiratory Syndrome Coronavirus Receptor and Activates Virus Entry. J. Virol. 2010, 85, 873-882. [CrossRef] [PubMed]

35. Zhao, Y.; Zhao, Z.; Wang, Y.; Zhou, Y.; Ma, Y.; Zuo, W. Single-Cell RNA Expression Profiling of ACE2, the Receptor of SARS-CoV-2. Am. J. Respir. Crit. Care Med. 2020, 202, 756-759. [CrossRef] [PubMed]

36. Smith, J.C.; Sausville, E.L.; Girish, V.; Yuan, M.L.; Vasudevan, A.; John, K.M.; Sheltzer, J.M. Cigarette Smoke Exposure and Inflammatory Signaling Increase the Expression of the SARS-CoV-2 Receptor ACE2 in the Respiratory Tract. Dev. Cell 2020, 53, 514-529.e3. [CrossRef] [PubMed]

37. Brosnihan, K.; Neves, L.; Anton, L.; Joyner, J.; Valdes, G.; Merrill, D. Enhanced expression of Ang-(1-7) during pregnancy. Braz. J. Med. Biol. Res. 2004, 37, 1255-1262. [CrossRef]

38. Narang, K.; Enninga, E.A.L.; Gunaratne, M.D.; Ibirogba, E.R.; Trad, A.T.A.; Elrefaei, A.; Theiler, R.N.; Ruano, R.; Szymanski, L.M.; Chakraborty, R.; et al. SARS-CoV-2 Infection and COVID-19 During Pregnancy: A Multidisciplinary Review. Mayo Clin. Proc. 2020, 95, 1750-1765. [CrossRef]

39. Li, M.; Chen, L.; Zhang, J.; Xiong, C.; Li, X. The SARS-CoV-2 receptor ACE2 expression of maternal-fetal interface and fetal organs by single-cell transcriptome study. PLoS ONE 2020, 15, e0230295. [CrossRef]

40. Bardon, V.F.; Isnard, P.; Roux, N.; Leruez-Ville, M.; Molina, T.; Bessieres, B.; Ville, Y. Protein expression of angiotensin-converting enzyme 2, a SARS-CoV -2-specific receptor, in fetal and placental tissues throughout gestation: New insight for perinatal counseling. Ultrasound Obstet. Gynecol. 2020, 57, 242-247. [CrossRef]

41. Levy, A.; Yagil, Y.; Bursztyn, M.; Barkalifa, R.; Scharf, S.; Yagil, C. ACE2 expression and activity are enhanced during pregnancy. Am. J. Physiol. Integr. Comp. Physiol. 2008, 295, R1953-R1961. [CrossRef]

42. Gengler, C.; Dubruc, E.; Favre, G.; Greub, G.; de Leval, L.; Baud, D. SARS-CoV-2 ACE-receptor detection in the placenta throughout pregnancy. Clin. Microbiol. Infect. 2020, 27, 489-490. [CrossRef]

43. Pique-Regi, R.; Romero, R.; Tarca, A.L.; Luca, F.; Xu, Y.; Alazizi, A.; Leng, Y.; Hsu, C.-D.; Gomez-Lopez, N. Does the human placenta express the canonical cell entry mediators for SARS-CoV-2? eLife 2020, 9, e58716. [CrossRef]

44. Valdés, G.; Neves, L.; Anton, L.; Corthorn, J.; Chacón, C.; Germain, A.; Merrill, D.; Ferrario, C.; Sarao, R.; Penninger, J.; et al. Distribution of Angiotensin-(1-7) and ACE2 in Human Placentas of Normal and Pathological Pregnancies. Placenta 2006, 27, 200-207. [CrossRef]

45. Kotlyar, A.M.; Grechukhina, O.; Chen, A.; Popkhadze, S.; Grimshaw, A.; Tal, O.; Taylor, H.S.; Tal, R. Vertical transmission of coronavirus disease 2019: A systematic review and meta-analysis. Am. J. Obstet. Gynecol. 2020, 224, 35-53.e3. [CrossRef]

46. Edlow, A.G.; Li, J.Z.; Collier, A.Y.; Atyeo, C.; James, K.E.; Boatin, A.A.; Gray, K.J.; Bordt, E.A.; Shook, L.L.; Yonker, L.M.; et al. Assessment of Maternal and Neonatal SARS-CoV-2 Viral Load, Transplacental Antibody Transfer, and Placental Pathology in Pregnancies During the COVID-19 Pandemic. JAMA Netw Open 2020, 3, e2030455. [CrossRef]

47. Jing, Y.; Run-Qian, L.; Hao-Ran, W.; Hao-Ran, C.; Ya-Bin, L.; Yang, G.; Fei, C. Potential influence of COVID-19/ACE2 on the female reproductive system. Mol. Hum. Reprod. 2020, 26, 367-373. [CrossRef]

48. Andersson, M.I.; Arancibia-Carcamo, C.V.; Auckland, K.; Baillie, J.K.; Barnes, E.; Beneke, T.; Bibi, S.; Brooks, T.; Carroll, M.; Crook, D.; et al. SARS-CoV-2 RNA detected in blood products from patients with COVID-19 is not associated with infectious virus. Wellcome Open Res. 2020, 5, 181. [CrossRef]

49. Definition and Categorization of the Timing of Mother-to-Child Transmission of SARS-CoV-2. Available online: https://www. who.int/publications-detail-redirect/WHO-2019-nCoV-mother-to-child-transmission-2021.1 (accessed on 30 August 2021). 
50. Sharps, M.C.; Hayes, D.J.; Lee, S.; Zou, Z.; Brady, C.A.; Almoghrabi, Y.; Kerby, A.; Tamber, K.K.; Jones, C.J.; Waldorf, K.M.A.; et al. A structured review of placental morphology and histopathological lesions associated with SARS-CoV-2 infection. Placenta 2020, 101, 13-29. [CrossRef]

51. Baergen, R.N.; Heller, D.S. Placental Pathology in Covid-19 Positive Mothers: Preliminary Findings. Pediatr. Dev. Pathol. 2020, 23, 177-180. [CrossRef]

52. Shanes, E.D.; Mithal, L.B.; Otero, S.; Azad, H.; Miller, E.S.; Goldstein, J. Placental Pathology in COVID-19. Am. J. Clin. Pathol. 2020, 154, 23-32. [CrossRef]

53. Yap, M.; Debenham, L.; Kew, T.; Chatterjee, S.R.; Allotey, J.; Stallings, E.; Coomar, D.; Lee, S.I.; Qiu, X.; Yuan, M.; et al. Clinical manifestations, prevalence, risk factors, outcomes, transmission, diagnosis and treatment of COVID-19 in pregnancy and postpartum: A living systematic review protocol. BMJ Open 2020, 10, e041868. [CrossRef]

54. Fenizia, C.; Biasin, M.; Cetin, I.; Vergani, P.; Mileto, D.; Spinillo, A.; Gismondo, M.R.; Perotti, F.; Callegari, C.; Mancon, A.; et al. Analysis of SARS-CoV-2 vertical transmission during pregnancy. Nat. Commun. 2020, 11, 1-10. [CrossRef]

55. Van Doorn, A.S.; Meijer, B.; Frampton, C.M.A.; Barclay, M.L.; De Boer, N.K.H. Systematic review with meta-analysis: SARS-CoV-2 stool testing and the potential for faecal-oral transmission. Aliment. Pharmacol. Ther. 2020. [CrossRef]

56. Carosso, A.; Cosma, S.; Borella, F.; Marozio, L.; Coscia, A.; Ghisetti, V.; Di Perri, G.; Benedetto, C. Pre-labor anorectal swab for SARS-CoV-2 in COVID-19 pregnant patients: Is it time to think about it? Eur. J. Obstet. Gynecol. Reprod. Biol. 2020, 249, 98-99. [CrossRef]

57. Hermesch, A.C.; Horve, P.; Edelman, A.; Dietz, L.; Constant, D.; Fretz, M.; Messer, W.B.; Martindale, R.; Wymelenberg, K.V.D. Severe Acute Respiratory Syndrome Coronavirus 2 (SARS-CoV-2) Environmental Contamination and Childbirth. Obstet. Gynecol. 2020, 136, 827-829. [CrossRef]

58. Raschetti, R.; Vivanti, A.J.; Vauloup-Fellous, C.; Loi, B.; Benachi, A.; De Luca, D. Synthesis and systematic review of reported neonatal SARS-CoV-2 infections. Nat. Commun. 2020, 11, 5164. [CrossRef]

59. Poon, L.C.; Yang, H.; Dumont, S.; Lee, J.C.S.; Copel, J.A.; Danneels, L.; Wright, A.; Costa, F.D.S.; Leung, T.Y.; Zhang, Y.; et al. ISUOG Interim Guidance on coronavirus disease 2019 (COVID-19) during pregnancy and puerperium: Information for healthcare professionals-An update. Ultrasound Obstet. Gynecol. 2020, 55, 848-862. [CrossRef]

60. CDC. Coronavirus Disease (COVID-19) and Breastfeeding. Available online: https://www.cdc.gov/breastfeeding/breastfeedingspecial-circumstances/maternal-or-infant-illnesses / covid-19-and-breastfeeding.html (accessed on 31 August 2021).

61. Centeno-Tablante, E.; Medina-Rivera, M.; Finkelstein, J.L.; Rayco-Solon, P.; Garcia-Casal, M.N.; Rogers, L.; Ghezzi-Kopel, K.; Ridwan, P.; Peña-Rosas, J.P.; Mehta, S. Transmission of SARS-CoV-2 through breast milk and breastfeeding: A living systematic review. Ann. N. Y. Acad. Sci. 2020, 1484, 32-54. [CrossRef]

62. World Health Organization. Breastfeeding and COVID-19: Scientific Brief, 23 June 2020; World Health Organization: Geneva, Switzerland, 2020.

63. Demers-Mathieu, V.; Do, D.M.; Mathijssen, G.B.; Sela, D.A.; Seppo, A.; Järvinen, K.M.; Medo, E. Difference in levels of SARS-CoV-2 S1 and S2 subunits- and nucleocapsid protein-reactive SIgM/IgM, IgG and SIgA/IgA antibodies in human milk. J. Perinatol. 2020, 41, 850-859. [CrossRef]

64. Legislative Portal. Available online: http://legislatie.just.ro/Public/DetaliiDocument/223812?fbclid=IwAR03roBO_iSyatI4H_ FrBj_16_4TChh_9-asAulZ8Z1tIXtwlMtFR5iDMSA (accessed on 6 July 2021).

65. Chen, Y.; Peng, H.; Wang, L.; Zhao, Y.; Zeng, L.; Gao, H.; Liu, Y. Infants Born to Mothers with a New Coronavirus (COVID-19). Front. Pediatr. 2020, 8, 104. [CrossRef]

66. Zhu, H.; Wang, L.; Fang, C.; Peng, S.; Zhang, L.; Chang, G.; Xia, S.; Zhou, W. Clinical analysis of 10 neonates born to mothers with 2019-nCoV pneumonia. Transl. Pediatr. 2020, 9, 51-60. [CrossRef]

67. Chen, H.; Guo, J.; Wang, C.; Luo, F.; Yu, X.; Zhang, W.; Li, J.; Zhao, D.; Xu, D.; Gong, Q.; et al. Clinical characteristics and intrauterine vertical transmission potential of COVID-19 infection in nine pregnant women: A retrospective review of medical records. Lancet 2020, 395, 809-815. [CrossRef]

68. Zeng, H.; Xu, C.; Fan, J.; Tang, Y.; Deng, Q.; Zhang, W.; Long, X. Antibodies in Infants Born to Mothers With COVID-19 Pneumonia. JAMA 2020, 323, 1848-1849. [CrossRef] [PubMed]

69. Dong, L.; Tian, J.; He, S.; Zhu, C.; Wang, J.; Liu, C.; Yang, J. Possible Vertical Transmission of SARS-CoV-2 From an Infected Mother to Her Newborn. JAMA 2020, 323, 1846-1848. [CrossRef] [PubMed]

70. Zamaniyan, M.; Ebadi, A.; Aghajanpoor, S.; Rahmani, Z.; Haghshenas, M.; Azizi, S. Preterm delivery, maternal death, and vertical transmission in a pregnant woman with COVID-19 infection. Prenat. Diagn. 2020, 40, 1759-1761. [CrossRef] [PubMed]

71. Alzamora, M.C.; Paredes, T.; Caceres, D.; Webb, C.; Valdez, L.M.; La Rosa, M. Severe COVID-19 during Pregnancy and Possible Vertical Transmission. Am. J. Perinatol. 2020, 37, 861-865. [CrossRef]

72. Hu, X.; Gao, J.; Luo, X.; Feng, L.; Liu, W.; Chen, J.; Benachi, A.; De Luca, D.; Chen, L. Severe Acute Respiratory Syndrome Coronavirus 2 (SARS-CoV-2) Vertical Transmission in Neonates Born to Mothers with Coronavirus Disease 2019 (COVID-19) Pneumonia. Obstet. Gynecol. 2020, 136, 65-67. [CrossRef]

73. Vivanti, A.J.; Vauloup-Fellous, C.; Prevot, S.; Zupan, V.; Suffee, C.; Cao, J.D.; Benachi, A.; De Luca, D. Transplacental transmission of SARS-CoV-2 infection. Nat. Commun. 2020, 11, 3572. [CrossRef] 
74. Rebello, C.M.; Fascina, L.P.; Annicchino, G.; Pinho, J.R.R.; Yoshida, R.D.A.M.; Zacharias, R.S.B. Vertical transmission of SARSCoV-2 from infected pregnant mother to the neonate detected by cord blood real-time polymerase chain reaction (RT-PCR). Pediatr. Res. 2020, 89, 1592-1593. [CrossRef]

75. Facchetti, F.; Bugatti, M.; Drera, E.; Tripodo, C.; Sartori, E.; Cancila, V.; Papaccio, M.; Castellani, R.; Casola, S.; Boniotti, M.B.; et al. SARS-CoV2 vertical transmission with adverse effects on the newborn revealed through integrated immunohistochemical, electron microscopy and molecular analyses of Placenta. EBioMedicine 2020, 59, 102951. [CrossRef]

76. Rodrigues, M.; Gasparinho, G.; Sepúlveda, F.; Matos, T. Signs suggestive of congenital SARS-CoV-2 infection with intrauterine fetal death: A case report. Eur. J. Obstet. Gynecol. Reprod. Biol. 2020, 256, 508-509. [CrossRef]

77. Valdespino-Vázquez, M.Y.; Helguera-Repetto, C.A.; León-Juárez, M.; Villavicencio-Carrisoza, O.; Flores-Pliego, A.; MorenoVerduzco, E.R.; Díaz-Pérez, D.L.; Villegas-Mota, I.; Carrasco-Ramírez, E.; López-Martínez, I.E.; et al. Fetal and placental infection with SARS-CoV-2 in early pregnancy. J. Med Virol. 2021, 93, 4480-4487. [CrossRef]

78. Blumberg, D.A.; Underwood, M.A.; Hedriana, H.; Lakshminrusimha, S. Vertical Transmission of SARS-CoV-2: What is the Optimal Definition? Am. J. Perinatol. 2020, 37, 769-772. [CrossRef]

79. Wong, Y.P.; Khong, T.Y.; Tan, G.C. The Effects of COVID-19 on Placenta and Pregnancy: What Do We Know So Far? Diagnostics 2021, 11, 94. [CrossRef]

80. Shah, P.S.; Diambomba, Y.; Acharya, G.; Morris, S.K.; Bitnun, A. Classification system and case definition for SARS-CoV-2 infection in pregnant women, fetuses, and neonates. Acta Obstet. Gynecol. Scand. 2020, 99, 565-568. [CrossRef]

81. Masuzaki, H.; Miura, K.; Miura, S.; Yoshiura, K.-I.; Mapendano, C.K.; Nakayama, D.; Yoshimura, S.; Niikawa, N.; Ishimaru, T. Labor Increases Maternal DNA Contamination in Cord Blood. Clin. Chem. 2004, 50, 1709-1711. [CrossRef]

82. Schwartz, D.A.; Mohagheghi, P.; Beigi, B.; Zafaranloo, N.; Moshfegh, F.; Yazdani, A. Spectrum of neonatal COVID-19 in Iran: 19 infants with SARS-CoV-2 perinatal infections with varying test results, clinical findings and outcomes. J. Matern. Neonatal Med. 2020, 1-10. [CrossRef]

83. Penfield, C.A.; Brubaker, S.G.; Limaye, M.A.; Lighter, J.; Ratner, A.J.; Thomas, K.M.; Meyer, J.A.; Roman, A. Detection of severe acute respiratory syndrome coronavirus 2 in placental and fetal membrane samples. Am. J. Obstet. Gynecol. MFM 2020, $2,100133$. [CrossRef]

84. Baud, D.; Greub, G.; Favre, G.; Gengler, C.; Jaton, K.; Dubruc, E.; Pomar, L. Second-Trimester Miscarriage in a Pregnant Woman With SARS-CoV-2 Infection. JAMA 2020, 323, 2198-2200. [CrossRef]

85. Eberle, C.; James-Todd, T.; Stichling, S. SARS-CoV-2 in diabetic pregnancies: A systematic scoping review. BMC Pregnancy Childbirth 2021, 21, 1-10. [CrossRef]

86. Hartmann-Boyce, J.; Morris, E.; Goyder, C.; Kinton, J.; Perring, J.; Nunan, D.; Mahtani, K.; Buse, J.B.; Del Prato, S.; Ji, L.; et al. Diabetes and COVID-19: Risks, Management, and Learnings from Other National Disasters. Diabetes Care 2020, 43, 1695-1703. [CrossRef]

87. Carbillon, L.; Fermaut, M.; Benbara, A.; Boujenah, J. COVID-19, Virchow's triad and thromboembolic risk in obese pregnant women. Clin. Cardiol. 2021, 44, 593-594. [CrossRef]

88. Calcaterra, G.; Bassareo, P.P.; Mehta, J.L. Letter in response to “ COVID -19, Virchow's triad and thromboembolic risk in obese pregnant women". Clin. Cardiol. 2021, 44, 595. [CrossRef]

89. Gheblawi, M.; Wang, K.; Viveiros, A.; Nguyen, Q.; Zhong, J.-C.; Turner, A.J.; Raizada, M.K.; Grant, M.B.; Oudit, G.Y. AngiotensinConverting Enzyme 2: SARS-CoV-2 Receptor and Regulator of the Renin-Angiotensin System. Circ. Res. 2020, 126, 1456-1474. [CrossRef]

90. Mendoza, M.; Garcia-Ruiz, I.; Maiz, N.; Rodo, C.; Garcia-Manau, P.; Serrano, B.; Lopez-Martinez, R.M.; Balcells, J.; FernandezHidalgo, N.; Carreras, E.; et al. Pre-eclampsia-like syndrome induced by severe COVID-19: A prospective observational study. BJOG Int. J. Obstet. Gynaecol. 2020, 127, 1374-1380. [CrossRef]

91. Coronado-Arroyo, J.C.; Concepción-Zavaleta, M.J.; Zavaleta-Gutiérrez, F.E.; Concepción-Urteaga, L.A. Is COVID-19 a risk factor for severe preeclampsia? Hospital experience in a developing country. Eur. J. Obstet. Gynecol. Reprod. Biol. 2020, 256, 502-503. [CrossRef]

92. Todros, T.; Masturzo, B.; De Francia, S. COVID-19 infection: ACE2, pregnancy and preeclampsia. Eur. J. Obstet. Gynecol. Reprod. Biol. 2020, 253, 330. [CrossRef]

93. Patberg, E.T.; Adams, T.; Rekawek, P.; Vahanian, S.A.; Akerman, M.; Hernandez, A.; Rapkiewicz, A.V.; Ragolia, L.; Sicuranza, G.; Chavez, M.R.; et al. Coronavirus disease 2019 infection and placental histopathology in women delivering at term. Am. J. Obstet. Gynecol. 2020, 224, 382.e1-382.e18. [CrossRef]

94. Mor, G.; Cardenas, I. The Immune System in Pregnancy: A Unique Complexity. Am. J. Reprod. Immunol. 2010, 63, 425-433. [CrossRef]

95. Ander, S.E.; Diamond, M.S.; Coyne, C.B. Immune responses at the maternal-fetal interface. Sci. Immunol. 2019,4 , eaat6114. [CrossRef]

96. Zhao, X.; Jiang, Y.; Zhao, Y.; Xi, H.; Liu, C.; Qu, F.; Feng, X. Analysis of the susceptibility to COVID-19 in pregnancy and recommendations on potential drug screening. Eur. J. Clin. Microbiol. Infect. Dis. 2020, 39, 1209-1220. [CrossRef]

97. Karimi-Zarchi, M.; Neamatzadeh, H.; Dastgheib, S.A.; Abbasi, H.; Mirjalili, S.R.; Behforouz, A.; Ferdosian, F.; Bahrami, R. Vertical Transmission of Coronavirus Disease 19 (COVID-19) from Infected Pregnant Mothers to Neonates: A Review. Fetal Pediatr. Pathol. 2020, 39, 246-250. [CrossRef] 
98. Racicot, K.; Kwon, J.-Y.; Aldo, P.; Silasi, M.; Mor, G. Understanding the Complexity of the Immune System during Pregnancy. Am. J. Reprod. Immunol. 2014, 72, 107-116. [CrossRef] [PubMed]

99. Tay, M.Z.; Poh, C.M.; Rénia, L.; Macary, P.A.; Ng, L.F.P. The trinity of COVID-19: Immunity, inflammation and intervention. Nat. Rev. Immunol. 2020, 20, 363-374. [CrossRef] [PubMed]

100. Blanco-Melo, D.; Nilsson-Payant, B.E.; Liu, W.-C.; Uhl, S.; Hoagland, D.; Møller, R.; Jordan, T.X.; Oishi, K.; Panis, M.; Sachs, D.; et al. Imbalanced Host Response to SARS-CoV-2 Drives Development of COVID-19. Cell 2020, 181, 1036-1045.e9. [CrossRef] [PubMed]

101. Guo, Y.-R.; Cao, Q.-D.; Hong, Z.-S.; Tan, Y.-Y.; Chen, S.-D.; Jin, H.-J.; Tan, K.-S.; Wang, D.-Y.; Yan, Y. The origin, transmission and clinical therapies on coronavirus disease 2019 (COVID-19) outbreak-An update on the status. Mil. Med. Res. 2020, 7, 1-10. [CrossRef]

102. Huang, C.; Wang, Y.; Li, X.; Ren, L.; Zhao, J.; Hu, Y.; Zhang, L.; Fan, G.; Xu, J.; Gu, X.; et al. Clinical features of patients infected with 2019 novel coronavirus in Wuhan, China. Lancet 2020, 395, 497-506. [CrossRef]

103. Fu, Y.; Cheng, Y.; Wu, Y. Understanding SARS-CoV-2-Mediated Inflammatory Responses: From Mechanisms to Potential Therapeutic Tools. Virol. Sin. 2020, 35, 266-271. [CrossRef]

104. Qin, C.; Zhou, L.; Hu, Z.; Zhang, S.; Yang, S.; Tao, Y.; Xie, C.; Ma, K.; Shang, K.; Wang, W.; et al. Dysregulation of Immune Response in Patients with Coronavirus 2019 (COVID-19) in Wuhan, China. Clin. Infect. Dis. 2020, 71, 762-768. [CrossRef]

105. Zhou, Y.; Fu, B.; Zheng, X.; Wang, D.; Zhao, C.; Qi, Y.; Sun, R.; Tian, Z.; Xu, X.; Wei, H. Pathogenic T-cells and inflammatory monocytes incite inflammatory storms in severe COVID-19 patients. Natl. Sci. Rev. 2020, 7, 998-1002. [CrossRef]

106. Kang, S.; Tanaka, T.; Inoue, H.; Ono, C.; Hashimoto, S.; Kioi, Y.; Matsumoto, H.; Matsuura, H.; Matsubara, T.; Shimizu, K.; et al. IL-6 trans-signaling induces plasminogen activator inhibitor-1 from vascular endothelial cells in cytokine release syndrome. Proc. Natl. Acad. Sci. USA 2020, 117, 22351-22356. [CrossRef]

107. Connors, J.M.; Levy, J.H. COVID-19 and its implications for thrombosis and anticoagulation. Blood 2020, 135, 2033-2040. [CrossRef]

108. Channappanavar, R.; Perlman, S. Pathogenic human coronavirus infections: Causes and consequences of cytokine storm and immunopathology. Semin. Immunopathol. 2017, 39, 529-539. [CrossRef]

109. Teuwen, L.-A.; Geldhof, V.; Pasut, A.; Carmeliet, P. COVID-19: The vasculature unleashed. Nat. Rev. Immunol. 2020, 20 , 389-391. [CrossRef]

110. Varga, Z.; Flammer, A.J.; Steiger, P.; Haberecker, M.; Andermatt, R.; Zinkernagel, A.S.; Mehra, M.R.; Schuepbach, R.; Ruschitzka, F.; Moch, H. Endothelial cell infection and endotheliitis in COVID-19. Lancet 2020, 395, 1417-1418. [CrossRef]

111. Wu, Z.; McGoogan, J.M. Characteristics of and Important Lessons from the Coronavirus Disease 2019 (COVID-19) Outbreak in China: Summary of a Report of 72314 Cases from the Chinese Center for Disease Control and Prevention. JAMA 2020, 323, 1239-1242. [CrossRef]

112. Li, X.; Sun, X.; Carmeliet, P. Hallmarks of Endothelial Cell Metabolism in Health and Disease. Cell Metab. 2019, $30,414-433$. [CrossRef]

113. Tudoran, C.; Tudoran, M.; Lazureanu, V.; Marinescu, A.; Pop, G.; Pescariu, A.; Enache, A.; Cut, T. Evidence of Pulmonary Hypertension after SARS-CoV-2 Infection in Subjects without Previous Significant Cardiovascular Pathology. J. Clin. Med. 2021, 10, 199. [CrossRef]

114. Dumache, R.; Daescu, E.; Ciocan, V.; Mureşan, C.; Talida, C.; Gavrilita, D.; Enache, A. Molecular Testing of SARS-CoV-2 Infection from Blood Samples in Disseminated Intravascular Coagulation (DIC) and Elevated D-Dimer Levels. Clin. Lab. 2021, 67. [CrossRef]

115. Tudoran, M.; Tudoran, C.; Lazureanu, V.; Marinescu, A.; Pop, G.; Pescariu, A.; Enache, A.; Cut, T. Alterations of Left Ventricular Function Persisting during Post-Acute COVID-19 in Subjects without Previously Diagnosed Cardiovascular Pathology. J. Pers. Med. 2021, 11, 225. [CrossRef]

116. Tudoran, M.; Tudoran, C.; Vlad, M.; Balas, M.; Abu Awwad, A.; Pop, G.N. Impact of Therapy with L-Thyroxine on the Evolution of Arterial and Aortic Stiffness in Female Patients with Overt and Subclinical Hypothyroidism. Rev. Chim. 2019, 70, 1372-1376. [CrossRef]

117. Bai, H.X.; Hsieh, B.; Xiong, Z.; Halsey, K.; Choi, J.W.; Tran, T.M.L.; Pan, I.; Shi, L.-B.; Wang, D.-C.; Mei, J.; et al. Performance of Radiologists in Differentiating COVID-19 from Non-COVID-19 Viral Pneumonia at Chest CT. Radiology 2020, 296, E46-E54. [CrossRef]

118. Harcourt, J.; Tamin, A.; Lu, X.; Kamili, S.; Sakthivel, S.K.; Murray, J.; Queen, K.; Tao, Y.; Paden, C.R.; Zhang, J.; et al. Severe Acute Respiratory Syndrome Coronavirus 2 from Patient with Coronavirus Disease, United States. Emerg. Infect. Dis. 2020, 26, 1266-1273. [CrossRef]

119. Zhang, H.; Zhou, P.; Wei, Y.; Yue, H.; Wang, Y.; Hu, M.; Zhang, S.; Cao, T.; Yang, C.; Li, M.; et al. Histopathologic Changes and SARS-CoV-2 Immunostaining in the Lung of a Patient With COVID-19. Ann. Intern. Med. 2020, 172, 629-632. [CrossRef]

120. Xiong, Y.; Liu, Y.; Cao, L.; Wang, D.; Guo, M.; Jiang, A.; Guo, D.; Hu, W.; Yang, J.; Tang, Z.; et al. Transcriptomic characteristics of bronchoalveolar lavage fluid and peripheral blood mononuclear cells in COVID-19 patients. Emerg. Microbes Infect. 2020, 9 , 761-770. [CrossRef] 
121. Falasca, L.; Nardacci, R.; Colombo, D.; Lalle, E.; Di Caro, A.; Nicastri, E.; Antinori, A.; Petrosillo, N.; Marchioni, L.; Biava, G.; et al. Postmortem Findings in Italian Patients With COVID-19: A Descriptive Full Autopsy Study of Cases with and Without Comorbidities. J. Infect. Dis. 2020, 222, 1807-1815. [CrossRef]

122. Zhang, H.; Penninger, J.M.; Li, Y.; Zhong, N.; Slutsky, A.S. Angiotensin-converting enzyme 2 (ACE2) as a SARS-CoV-2 receptor: Molecular mechanisms and potential therapeutic target. Intensiv. Care Med. 2020, 46, 586-590. [CrossRef]

123. Diao, B.; Wang, C.; Wang, R.; Feng, Z.; Zhang, J.; Yang, H.; Tan, Y.; Wang, H.; Wang, C.; Liu, L.; et al. Human kidney is a target for novel severe acute respiratory syndrome coronavirus 2 infection. Nat. Commun. 2021, 12, 1-9. [CrossRef]

124. Cheng, Y.; Luo, R.; Wang, K.; Zhang, M.; Wang, Z.; Dong, L.; Li, J.; Yao, Y.; Ge, S.; Xu, G. Kidney impairment is associated with in-hospital death of COVID-19 patients. MedRxiv 2020. [CrossRef]

125. Feng, G.; Zheng, K.; Yan, Q.-Q.; Rios, R.S.; Targher, G.; Byrne, C.D.; Van Poucke, S.; Liu, W.-Y.; Zheng, M.-H. COVID-19 and Liver Dysfunction: Current Insights and Emergent Therapeutic Strategies. J. Clin. Transl. Hepatol. 2020, 8, 1-7. [CrossRef]

126. Ernst, L.M. Maternal vascular malperfusion of the placental bed. APMIS 2018, 126, 551-560. [CrossRef]

127. Stonoga, E.T.S.; Lanzoni, L.D.A.; Rebutini, P.Z.; de Oliveira, A.L.P.; Chiste, J.A.; Fugaça, C.A.; Prá, D.M.M.; Percicote, A.P.; Rossoni, A.; Nogueira, M.B.; et al. Intrauterine Transmission of SARS-CoV-2. Emerg. Infect. Dis. 2021, 27, 638-641. [CrossRef] [PubMed]

128. Marinho, P.S.; da Cunha, A.J.L.A.; Chimelli, L.; Avvad-Portari, E.; Andreiuolo, F.D.M.; de Oliveira-Szejnfeld, P.S.; Mendes, M.A.; Gomes, I.C.; Souza, L.R.Q.; Guimarães, M.Z.; et al. Case Report: SARS-CoV-2 Mother-to-Child Transmission and Fetal Death Associated with Severe Placental Thromboembolism. Front. Med. 2021, 8, 1315. [CrossRef] [PubMed]

129. Stokes, E.K.; Zambrano, L.D.; Anderson, K.N.; Marder, E.P.; Raz, K.M.; Felix, S.E.B.; Tie, Y.; Fullerton, K.E. Coronavirus Disease 2019 Case Surveillance-United States, January 22-May 30, 2020. Morb. Mortal. Wkly. Rep. 2020, 69, 759-765. [CrossRef] [PubMed]

130. Götzinger, F.; Santiago-García, B.; Noguera-Julián, A.; Lanaspa, M.; Lancella, L.; Carducci, F.I.C.; Gabrovska, N.; Velizarova, S.; Prunk, P.; Osterman, V.; et al. COVID-19 in children and adolescents in Europe: A multinational, multicentre cohort study. Lancet Child Adolesc. Health 2020, 4, 653-661. [CrossRef]

131. Bixler, D.; Miller, A.D.; Mattison, C.P.; Taylor, B.; Komatsu, K.; Pompa, X.P.; Moon, S.; Karmarkar, E.; Liu, C.Y.; Openshaw, J.J.; et al. SARS-CoV-2-Associated Deaths Among Persons Aged <21 Years-United States, February 12-July 31, 2020. Morb. Mortal. Wkly. Rep. 2020, 69, 1324-1329. [CrossRef]

132. Liguoro, I.; Pilotto, C.; Bonanni, M.; Ferrari, M.E.; Pusiol, A.; Nocerino, A.; Vidal, E.; Cogo, P. SARS-COV-2 infection in children and newborns: A systematic review. Eur. J. Nucl. Med. Mol. Imaging 2020, 179, 1029-1046. [CrossRef]

133. Zachariah, P.; Johnson, C.L.; Halabi, K.C.; Ahn, D.; Sen, A.I.; Fischer, A.; Banker, S.L.; Giordano, M.; Manice, C.S.; Diamond, R.; et al. Epidemiology, Clinical Features, and Disease Severity in Patients with Coronavirus Disease 2019 (COVID-19) in a Children's Hospital in New York City, New York. JAMA Pediatr. 2020, 174, e202430. [CrossRef]

134. HAN Archive-00432 I Health Alert Network (HAN). Available online: https:/ / emergency.cdc.gov/han/2020/han00432.asp (accessed on 21 September 2021).

135. Multisystem Inflammatory Syndrome in Children and Adolescents with COVID-19. Available online: https://www.who.int/ publications-detail-redirect/multisystem-inflammatory-syndrome-in-children-and-adolescents-with-covid-19 (accessed on 21 September 2021).

136. Levin, M. Childhood Multisystem Inflammatory Syndrome-A New Challenge in the Pandemic. N. Engl. J. Med. 2020, 383, 393-395. [CrossRef]

137. Duarte-Neto, A.N.; Caldini, E.G.; Gomes-Gouvêa, M.S.; Kanamura, C.T.; Monteiro, R.A.D.A.; Ferranti, J.F.; Ventura, A.M.C.; Regalio, F.A.; Fiorenzano, D.M.; Gibelli, M.A.B.C.; et al. An autopsy study of the spectrum of severe COVID-19 in children: From SARS to different phenotypes of MIS-C. EClinicalMedicine 2021, 35, 100850. [CrossRef]

138. Dolhnikoff, M.; Duarte-Neto, A.N.; Monteiro, R.; Da Silva, L.F.F.; De Oliveira, E.P.; Saldiva, P.H.N.; Mauad, T.; Negri, E.M. Pathological evidence of pulmonary thrombotic phenomena in severe COVID-19. J. Thromb. Haemost. 2020, 18, 1517-1519. [CrossRef]

139. Goshua, G.; Pine, A.B.; Meizlish, M.; Chang, C.-H.; Zhang, H.; Bahel, P.; Baluha, A.; Bar, N.; Bona, R.D.; Burns, A.J.; et al. Endotheliopathy in COVID-19-associated coagulopathy: Evidence from a single-centre, cross-sectional study. Lancet Haematol. 2020, 7, e575-e582. [CrossRef]

140. Abdel-Mannan, O.; Eyre, M.; Löbel, U.; Bamford, A.; Eltze, C.; Hameed, B.; Hemingway, C.; Hacohen, Y. Neurologic and Radiographic Findings Associated With COVID-19 Infection in Children. JAMA Neurol. 2020, 77, 1440-1445. [CrossRef]

141. Dolhnikoff, M.; Ferranti, J.F.; Monteiro, R.; Duarte-Neto, A.N.; Gomes-Gouvêa, M.S.; Degaspare, N.V.; Delgado, A.F.; Fiorita, C.M.; Leal, G.N.; Rodrigues, R.M.; et al. SARS-CoV-2 in cardiac tissue of a child with COVID-19-related multisystem inflammatory syndrome. Lancet Child Adolesc. Health 2020, 4, 790-794. [CrossRef]

142. Sonzogni, A.; Previtali, G.; Seghezzi, M.; Alessio, M.G.; Gianatti, A.; Licini, L.; Morotti, D.; Zerbi, P.; Carsana, L.; Rossi, R.; et al. Liver histopathology in severe COVID 19 respiratory failure is suggestive of vascular alterations. Liver Int. 2020, 40, $2110-2116$. [CrossRef]

143. Su, H.; Yang, M.; Wan, C.; Yi, L.-X.; Tang, F.; Zhu, H.-Y.; Yi, F.; Yang, H.-C.; Fogo, A.B.; Nie, X.; et al. Renal histopathological analysis of 26 postmortem findings of patients with COVID-19 in China. Kidney Int. 2020, 98, 219-227. [CrossRef] 